\title{
Alonso de Orozco teólogo-cantor de las gracias de María
}

No se puede poner en duda que una de las facetas más sobresalientes, seguramente la más, de la personalidad religiosa de Alonso de Orozco es la devoción y el amor a María. Este pensamiento quiere ser el hilo conductor del trabajo que voy a realizar en homenaje a Alonso de Orozco con motivo del cuarto centenario de su muerte.

He calificado a Alonso de Orozco como teólogo y cantor de las gracias de María. No voy fuera de camino. El trabajo va a confirmarlo. Alonso de Orozco se manifiesta en sus exposiciones como teólogo. Incluso, como teólogo de excepción. Sus razonamientos se apoyan en verdaderas razones teológicas. No son mera sensiblería.

La mente no trabaja sola. Está acompañada del corazón. Alonso de Orozco no sólo investiga. Ama y ama sobre todo. Es lo que he querido expresar con la palabra cantor. Alonso de Orozco se ofrece así a sus lectores como teólogo y, sobre todo, como enamorado de María. Al tiempo que enseña, conmueve.

Para que el artículo no mire sólo al pasado y se traduzca en un simple florilegio de textos, que lógicamente es lo que va a constituir su parte más relevante y más larga, aprovecharé todas las ocasiones posibles para ampliar aspectos, que tengan algo que ver con las inquietudes de nuestro tiempo. Dicho de otro modo: intentaré no hacer arqueología, sino teología viva. Y ello con la esperanza que todo esto contribuya a sentir más cercano a un hombre del siglo XVI y a que la devoción a María se alimente de una teología más bíblica, más sólida y menos sentimental.

I

La figura de María es objeto en nuestros días de una literatura que, desde mi punto de vista, está resultando farragosa. Excesiva, al menos. 
Como tal, poco atrayente. En tiempos anteriores su figura fue revestida de una literatura dulzarrona y populista, hasta producir la impresión de que su figura venía a estar por encima de la de nuestro adorable Redentor. El concilio Vaticano II, que ha colocado a María en su puesto, es decir, en el misterio de Cristo y de la iglesia, su esposa, ha escrito un capítulo verdaderamente admirable, (aquí faltan los calificativos), por la solidez de la doctrina y por la sobriedad del tono y del estilo. El capítulo VIII de la Lumen Gentium tiene tales calidades teológicas y un estilo tan cercano al hombre de nuestro tiempo que no dudo en considerarlo como lo mejor que se ha escrito de María. En ese capítulo hay una seria advertencia. Una advertencia que, a poco de entendido, se hace eco de la crítica protestante sobre el excesivo protagonismo que se ha dado a María en el catolicismo. "Asimismo exhorta (el Concilio) encarecidamente a los teólogos y a los predicadores que se abstengan con cuidado de toda falsa exageración como también de una excesiva estrechez de espíritu, al considerar la singular dignidad de la Madre de Dios" 1.

En siglos pasados, y no tan pasados, se cultivó la teología mariana de los títulos. Su expresión más significativa, por su incidencia popular, fue la letanía del Rosario. Hay títulos recargados e incluso repetidos. María es purísima, inmaculada, sin tacha, intacta. Se ve en toda esta literatura una cierta manía por el tema de la pureza como opuesto a lo impuro. En el fondo, es una visión pesimista de todo lo que huela a materia y a cuerpo. Puro e impuro es un binomio cargado de resonancias platónicas, imposible de sostener hoy.

Teología de los títulos. Una teología sin mayor base bíblica. Dominada por el sentimentalismo. Y la imaginación. Una pobre teología, que encubría su pobreza con el número. Recuerdo al respecto una pintura, salida años ha en la revista "Vida Nueva". El cuadro recogía los siguientes personajes: María con el niño, un ángel y José, como perdido en un rincón del cuadro. El ángel estaba echando piropos a María, recogiendo y recordando diversos títulos de la letanía del Rosario. José estaba como dormido, al menos como distraído. De pronto, como si despertara de un sueño o superara su distracción, cansado de oír cosas al ángel, exclama: simplemente María. ¡Maravilloso! Esto sí que es verdadera captación de las cosas. ¡Cómo ha sabido José retratar bellamente a su esposa y a la madre de su hijo Jesús! La figura de María aparece en las palabras de José tan sencilla y tan cercana a los hombres y mujeres que no es posible rechazarla.

1. LG 67. 
La teología de los títulos parece que no llama ya la atención, si no es a algún sentimental. No obstante, y a pesar de la lección de la historia, ahora estamos en otro extremismo que no ayuda, ni mucho menos, a sentir atractivo por la figura de María. A este fenómeno yo lo llamo "la teología de las buenas obras". Ello hace buscar, mejor re-buscar con toda la carga negativa que esta palabra lleva consigo, aspectos novedosos de la vida de María, a los que no puede acceder una correcta reflexión teológica. Sólo una imaginación calenturienta y un corazón loco y desbordado pueden trabajar aquí. Las obras, obrillas muchas veces, sobre María se multiplican como las ratas. Perdónese la expresión. Y es normal que, en tanta profusión, se digan muchas incoherencias y se haga una adorarión excesiva a los tópicos. Lo cierto es que la figura de María, esencialmente atrayente por su sencillez, termina por resultar, si no antipática, sí desagradable. Uno llega a sentirla muy lejana. Hasta puede surgir un cierto gesto de indiferencia. ¿Qué puede decirme todo eso y en qué me puede servir de estímulo? Nada y en nada. María aparece tan rodeada de proteccionismo divino, que parece que no puede obrar de otra manera. De este modo, su libertad y su respuesta a la gracia quedan mal-paradas. Hasta se llega a tener la impresión que hablar de María es sencillamente inútil e incomprensible.

Para salir de este atolladero, o de este callejón sin salida fácil, no queda otro camino que situar a María en el misterio de Cristo y de la iglesia, su esposa. Es el gran mensaje de un teólogo de la altura de Agustín. Oigamos sus palabras, que, con seguridad, van a dejarnos perplejos: "María es santa, María es bienaventurada, pero la iglesia es mejor que la Virgen María. ¿Por qué? Porque María es una parte de la iglesia, un miembro excelente, un miembro fuera de serie, pero, en definitiva, un miembro del cuerpo total. $\mathrm{Si}$ ella es una parte del cuerpo total, resulta evidente que el cuerpo es más grande que sus miembros" ${ }^{2}$. Amplío con otro maravilloso texto esta doctrina. "Ved o considerad de qué modo es la iglesia... madre de Cristo. María virgen la precedió con su tipo. ¿Por qué es María madre de Cristo, si no es porque dio a luz al cuerpo de Cristo? Vosotros, a quienes yo estoy hablando en estos momentos, sois miembros de Cristo. ¿Quién os dio a luz? Oigo la voz de vuestro corazón: la madre iglesia. Esta madre santa y honrada, semejante a María, y da a luz y es virgen. Que da a luz lo pruebo por vosotros mismos: habéis nacido de ella. Y da a luz a Cristo, porque vosotros sois miembros de Cristo. He probado que pare. Probaré que es virgen. No me 
abandona el testimonio divino. 'Os he desposado con un solo varón, para que os mostréis para Cristo una casta virgen'. ¿En dónde está la virginidad? ¿Donde se teme la corrupción? Temo, pues, dice, que así como la serpiente sedujo a Eva por su astucia, así vuestras mentes se aparten, se alejen de la castidad que está en Cristo Jesús (cf. 1Cor 11,2.3). Mantened en las mentes la virginidad: la virginidad de la mente es la integridad de la fe católica. En donde Eva fue corrompida por la palabra de la serpiente, allí debe estar la virgen iglesia por el don del Omnipotente... Fuisteis hijos, sed también madres. Hijos de la madre, al ser bautizados, fuisteis miembros de Cristo: llevad a la fuente del bautismo a todos los que podáis; para que, como fuisteis hijos al nacer, así, llevando a nacer, podáis ser madres de Cristo" ${ }^{3}$.

¡Admirable! Verdaderamente admirable. Agustín tiene intuiciones geniales. Hay que fijarse en algunos detalles para percibir así la fuerza del pensamiento agustiniano. Hablando de María, Agustín dice que es tipo de la iglesia. Esta forma de hablar es muy propia de los Padres de la iglesia. Ellos descubrieron frecuentes tipos de Cristo en el Antiguo Testamento. Adán, por ejemplo, fue tipo de Cristo, el nuevo Adán. Cristo es, por tanto, el antitipo de Adán. El tipo es la imagen. El anti-tipo es la realidad. Cuanto supera la realidad a la imagen, tanto supera el anti-tipo al tipo. Al afirmar Agustín que María es tipo de la iglesia está poniendo de manifiesto que la iglesia es el anti-tipo. Es decir, que la mayor densidad de ser, tanto en la maternidad como en la virginidad, corresponde a la iglesia. Si María es madre, la Iglesia, si cabe la expresión, es más madre. Si María es virgen, la iglesia es más virgen. Siguiendo en esta misma línea, quiero recordar ahora el discurso pronunciado por Pablo VI el 21 de noviembre de 1964. En este discurso Pablo VI proclama a María madre de la iglesia. Oigamos sus palabras: "Así, pues, para gloria de la Virgen y consuelo nuestro, Nos proclamamos a María Santísima 'Madre de la iglesia', es decir madre de todo el pueblo de Dios, tanto de los fieles como de los pastores, que la llaman madre amorosa y queremos que de ahora en adelante sea honrada e invocada por todo el pueblo cristiano con este gratísimo título" ". No hay que dudar que el papa da un tono elevado a sus palabras. Sin llegar a la solemnidad de un acto supremo de magisterio, hay que reconocer que las palabras del papa alcanzan un tono muy subido. Es necesario mirarlas con gran respeto.

Esto por delante, es preciso reconocer que su declaración puede dar ocasión a malentendidos teológicos. Si uno no extrema el cuidado, puede lle-

3. S. Denis, 25,8; ML 163.

4. Documentos pontificios complementarios. En concilio Vaticano II, BAC, Madrid, 1965, n. 25, 793. 
gar a pensar equivocadamente que María, al ser madre de la iglesia, es un miembro fuera de ella. Lo cual como fácilmente se puede entender, no es correcto. María es un miembro, eso sí un miembro cualificado, de la iglesia. Pero, al fin y al cabo, un miembro.

El antitipo paulino, por lo que respecta al tema, es Cristo-iglesia. No Cristo-María. Nuestros padres, padre y madre, en la nueva creación son Cristo y la iglesia. Adán-Eva es el tipo. Cristo-Iglesia, el anti-tipo. Agustín bebe en Pablo, a la hora de hablarnos de Cristo y la iglesia.

Como el tema es rico en contenido, y profundamente teológico, me permito seguir reflexionando sobre él. Hay un libro, precioso por cierto, de Max Thurian, de su época calvinista, sobre María, que tiene este sugestivo título: "María, madre del Señor, figura de la iglesia". En él encontramos verdaderos tesoros a la hora de reflexionar sobre María. Y sorprende, por venir de quien viene: un protestante. "María, dice, se nos manifiesta como figura de la iglesia nuestra Madre. Nos ayuda a considerar la maternidad de la iglesia en su ministerio. Cuando pensamos en el misterio de la iglesia, debemos pensar en María, su figura (su tipo), para comprender su maternidad espiritual. La iglesia es la esposa de Cristo: 'la amó y se entregó por ella, para santificarla en el baño de agua al que acompaña una palabra, pues quiso presentársela sin mancha, ni arruga, ni cosa semejante, sino santa e inmaculada...; la mantiene y cuida (Ef 25.32).

Y san Pablo añadía a esta descripción conyugal de la iglesia: 'este misterio tiene gran alcance; quiero decir que se aplica a Cristo y la iglesia'. Si, para san Pablo, la unión conyugal del cristiano y su esposa es un signo simbólico, un misterio, que orienta nuestro espíritu hacia la realidad del amor de Cristo para con la iglesia, su esposa, para san Juan la maternidad de María con relación a Jesús y al discípulo bien-amado, hermano de Jesús, es un signo simbólico, un misterio que orienta nuestro espíritu hacia la realidad del amor de la iglesia nuestra madre para con nosotros. El misterio de María tiene también gran alcance: se aplica a la iglesia, madre de los fieles, hermanos de Cristo.

La iglesia da a luz, alimenta, consuela, cuida de los hijos del Padre, hermanos de Cristo, en el poder del Espíritu Santo. Por la palabra de Dios y el bautismo, da a luz en la fe, la esperanza y la caridad a los nuevos creyentes; por la eucaristía, los alimenta con el cuerpo y la sangre vivificante del Señor; por la unción y la imposición de las manos, les da la curación del alma y del cuerpo" ${ }^{6}$.

6. María, madre del Señor, figura de la iglesia. Ed. Hechos y dichos. Hoy desaparecida, Zaragoza 1966, 244-245. 
En atención a lo dicho, parece que la fórmula teológicamente más acertada es María, madre en la iglesia y no María, madre de la iglesia. Aunque las dos fórmulas son teológicamente válidas, siempre que se entiendan bien, la primera es más densa de contenido y más en conformidad con el mensaje bíblico y apostólico. Además, la primera es más rica desde el punto de vista dinámico y existencial. Entran ahora en acción los carismas, tan queridos para Pablo. Según este punto de vista, el carisma de María es ser madre en el misterio de la iglesia, a la que pertenece como miembro cualificado. ¡Hermosa expresión la subrayada! A María le compete, bajo la acción del Espíritu Santo, derramar ternura y amor maternales en el amplio tejido eclesial.

Todo esto queda confirmado por la doctrina del concilio Vaticano II. Este Concilio, concilio de nuestro tiempo, ha elaborado sobre María una doctrina sugestiva al cien por cien. Sitúa a María en el misterio de Cristo. No aparte. Que es lo mismo que situarla en el misterio de la iglesia, ya que Cristo es ininteligible sin la iglesia. Sería, por principio, un Cristo mutilado. Hay en la exposición del Concilio equilibrio y profundidad teológicos. La buena devoción a María tiene que alimentarse de la teología, si no quiere degenerar en sentimentalismo injustificado. Mi deseo es ofrecer este cambio a los lectores. Al tiempo, presentar la figura de Alonso de Orozco, un agustino del siglo XVI que se distinguió por su devoción a María. Que cantó sus gracias y las dio consistencia teológica. Debido a ello le he calificado como teólogo y cantor de las gracias de María.

II

Alonso de Orozco nace y vive en un siglo español especialmente brillante en la literatura y en la teología. Son muchos los soles esplendorosos que adornan el firmamento de la España del siglo XVI. De ahí que no queda fácil dejar sentir la luz en un firmamento tan cargado de soles luminosos. Tal vez esté aquí la razón de por qué Alonso de Orozco ha quedado un tanto relegado a segundo o tercer grado. "Las exigencias de la perspectiva histórica han colocado en segundo o tercer plano la casi borrada figura del beato Orozco. El análisis detallado de sus rasgos nos hace ver la importancia merecida que en su tiempo consiguiera su valer y sus virtudes y nos hace sentir que su fisonomía haya sido poco menos que cubierta por el polvo del olvido" ?

El siglo XVI es llamado con toda verdad el siglo de oro de España. España no es sólo la primera potencia militar del mundo, sino que también es la

7. HERRAN, L., Introducción al 'Tratado de la siete palabras que María Santísima habló del beato Orozco. Ed. Rialp, Madrid 1966, 9. 
primera potencia espiritual del planeta, si es que esta forma de hablar puede aplicarse al caos. "Conviene tener siempre presente que la reforma católica interna del siglo XVI fue un proceso sumamente variado, en el que participaron muy distintas fuerzas eclèsiales de muy diferentes maneras y no siempre de forma claramente coherente. Ya hemos visto cuán variadamente contribuyó Italia a este resurgimiento. Pero hemos de repetir aquí lo ya dicho, volviendo a resaltar su importancia: España es la que renovó el catolicismo. Su ardor religioso, su sentido católico-eclesiástico, la conciencia de su misión histórica frente a la infidelidad y su iglesia nacional, no exenta de amenazas y peligros, pero marcadamente fiel a la iglesia universal, alcanzaron el pleno apogeo de su fuerza al alcanzar también el país la cumbre de su desarrollo político y cultural. El país que regía los destinos del mundo en la época de la Reforma era católico. Se comprenden que las fuerzas católicas del siglo XVI fuesen primordialmente españolas... En nota 17 añade: Como para Francia el siglo XVII, para España la época clásica fue el siglo XVI: En España surgió la primera novela moderna, el primer drama moderno, el renacimiento de la Escolástica en Salamanca. Y las repercusiones políticas y económicas de sus descubrimientos y conquistas de Ultramar: España pasó a ser una potencia mundial y la primera potencia europea" 8 .

Tradicionalmente todo el movimiento de reforma, nacido en el catolicismo, se suele llamar Contrarreforma. Es como el reverso de la llamada Reforma, iniciada por el agustino Martín Lutero. Esta terminología, aunque tradicional, es equivocada. Y produce una impresión desagradable, ya que ordinariamente la Contrarreforma se considera como un movimiento regresivo y conservador. Un movimiento a contrapelo de la historia. "Cuando empecé mi investigación, se imponía todavía a la historia del cristianismo moderno el esquema de Prerreforma, Reforma y Contrarreforma. Pero quienes nos dedicamos a estos estudios hemos ido viendo cada vez mejor que la rebelión de Lutero no había abierto repentinamente una nueva era de la vida espiritual de Europa. Tan 'Reforma' era lo de antes de Lutero como lo de después. El mayor equívoco de esta terminología consistía en hacer de la Reforma un sinónimo anacrónico de Protestantismo, en adscribir a Contrarreforma todo lo vigoroso y nuevo después de 1517. Cuando lo que entre 1517 y 1560 merece en rigor el nombre de Contrarreforma es una actitud negativa, hostil a toda reforma, tanto católica como protestante, y que abomina poco menos a Erasmo, al Maestro Juan de Ávila, a los primeros jesuitas, que a Lutero y Calvino. Esquematizar la Reforma católica, de Lutero en

8. LoRtz, J., Historia de la iglesia, II. Ed. Cristiandad, 1982, 189. 
adelante, como Contrarreforma equivale a empobrecerla y el que la Compañía de Jesús, después de 1560, haya sido, más que otra cosa, una fuerza antiprotestante no quiere decir que san Ignacio haya sido, más que otra cosa, un antilutero. Finalmente, el propio término de Reforma, aceptable para aspectos eclesiásticos o monásticos de aquel gran movimiento, nos desorienta más bien acerca de un profundo carácter de renovación del sentimiento religioso" 9 .

Alonso de Orozco nace y vive en un momento de floración espiritual único en España. Todas las instituciones están impregnadas de espíritu evangélico. Y, aunque hay sus exageraciones e, incluso, sus deformaciones, hay que reconocer que España es, por entonces, una verdadera potencia espiritual. En este marco de referencia no es aventurado decir que Alonso de Orozco va a recibir una educación profundamente cristiana. Educación que va a tener un personaje de excepción: su propia madre. Precisamente su devoción a María le viene de casta materna. Sobre el tema tenemos datos preciosos ofrecidos por el mismo interesado. "Vos, mi Salvador, sabéis bien lo que mi madre, la primera vez que me vio religioso, ha más de cuarenta años, en Talavera, me contó, para gloria vuestra y gran gozo mío: 'Sabed, hijo, (me dijo), que estando yo preñada, pensaba dentro de mi a qué Santo os ofrecía, si fuéredes niño; o, si naciese niña, a que Santa llamaría en vuestro favor y os pondría su nombre. Era sierva vuestra. Llamábase mi madre María y muy devota de vuestra gloriosa Madre. Y tenía esta costumbre todas las veces que estaba preñada. Y aún díjome más: 'a dos hijos puse nombre de su abuelo, y de su padre, que se decía Hernando. Y todos me los llevó el Señor, siendo niños bautizados. Y desde allí determiné de jamás poner nombres por vía de linaje, sino de santos y santas. Y yo, una noche, estando despierta, y suplicando a nuestro Señor Jesucristo, que me inspirase qué nombre de Santo o de Santa os pondría en el santo bautismo, oí una voz muy suave, como de mujer, la cual dijo así: ¿Cómo le has de llamar, sino Alonso? Yo recibí gran alegría, porque la benditísima Virgen María, a quien yo invocaba por intercesora, me hubiese visitado y declarado la voluntad de su precioso Hijo, nuestro Señor Jesucristo. Y allí entendí dos cosas: la una, que lo que había de parir era varón; y la otra, que, pues, el Bienaventurado San Ildefonso fue tan celador de la pureza virginal de esta reina del cielo, que ella sería servida que yo os encaminase al estado eclesiástico, para que fueses capellán de esta Señora del mundo. Por tanto, aún en el día de vuestro bautismo, no consentí que llevaras paños labrados de seda, sino solamente

9. BAStaIlón, M., Erasmo y España. Fondo de cultura económica, Méjico 1986, XIII. 
blancos y dije así: Este niño tengo dedicado para capellán de la Madre de Dios, Virgen Santísima. Por eso quiero que todo lo que lleve sea blanco" ${ }^{10}$.

La narración es de verdad idílica y de una frescura espiritual cargada de aroma. Cuando se están leyendo estos recuerdos uno no puede por menos de recordar a Ana, la admirable madre de Samuel. Al igual que ésta dedica su hijo, el hijo conseguido por una oración ferviente, al servicio del templo, la madre de Alonso de Orozco quiere que su hijo entre por el camino del estado eclesiástico y se distinga por una excepcional devoción a la Madre de Dios.

En cumplimiento de los deseos de la madre, Alonso inicia muy pronto su preparación para entrar en el estado eclesiástico. Cuál sea el final de este camino todavía se escapa a las previsiones de Alonso de Orozco. Está en las manos de Dios y éste le irá indicando el camino concreto. De momento, se hace monaguillo en Talavera. Un inicio muy apropiado para ponerse en contacto con las cosas de la iglesia. Y del culto. Sirve en gran manera para despertar el sentimiento religioso del todavía niño. Luego, ejerce en Toledo, la flamente capital imperial, como reise, es decir, como miembro del coro que baila y canta en la catedral toledana. Otro paso muy en la línea de ponerse en contacto con las cosas de la iglesia y del culto. Cuando llega a la edad apropiada, pasa a Salamanca, para estudiar en su famosa universidad. En efecto, la universidad de Salamanca era, por entonces, una de las universidades más famosas del mundo. Estudiar en ella era un orgullo y suponía un privilegio asequible a pocos. Salamanca no es sólo lugar de sabios, sino que también es recinto de santos. Aquí vivían por aquella época dos grandes figuras agustinas: Tomás de Villanueva y Fr. Luis de León. En ella había vivido también otro santo agustino: Juan de Sahagún. Nacido en esta ilustre villa leonesa, Juan de Sahagún dio a Salamanca lo mejor de su predicación y de su vida. La ilustre ciudad lo ha reconocido. Hoy san Juan de Sahagún es patrono de Salamanca. Santo Tomás de Villanueva es gran profesor universitario. Pero, sobre todo, es hombre enamorado de Dios. Será más adelante gran arzobispo de Valencia. Su figura ejerce un embrujo especial sobre Alonso de Orozco. Fruto de ese embrujo es la entrada del Oropesano en la Orden de san Agustín. Profesa en manos de santo Tomás de Villanueva el 9 de junio de 1523. Alcanza en la Orden puestos de relevancia. Es Definidor general en el capítulo provincial de Dueñas (1541). Luego prior de Sevilla (1542-1544). Es aquí, en Sevilla, donde Alonso de Orozco recibe una visita de María, la Madre del Señor, que va a ser determinante para su misión de escritor. Oigamos sus palabras, bellas palabras: "Morando en nuestro

10. Alonso DE OROZCo, Confesiones, Obras III. Lib. 1, VI, 71. 
monasterio en Sevilla, y estando durmiendo, vi en sueños a vuestra purísima Madre, la cual me dijo una sola palabra. Y fue: escribe. Fue tan grande la alegría, que sintió mi alma, que no lo podía declarar por palabras. Su rostro era tan humilde y juntamente tan grave, y los ojos bajos, que ahora escribiendo me parece que la veo: de tal manera se impresionó en mi corazón aquella dichosa visita. Con esta alegría desperté y dije: Oh reina de los cielos, suplícoos que, si esta visión es verdadera, que me certifiquéis, si mandáis que escriba. Tornando a dormir la misma noche, volví a verla y díjome: 'escribe'. Alabé, Salvador mío, vuestra misericordia tan grande y di gracias a la Señora del mundo diciendo con santa Isabel: '¿de dónde merecí yo que la Madre de mi Señor me viniese a visitar y a consolar'". ${ }^{11}$.

Alonso de Orozco inicia su labor de escritor; recojo ahora algunos testimonios: "la originalidad y el mérito del libro (se refiere a "Siete palabras de la Virgen") está, pues, en ser, en primer lugar un libro en el que se vulgarizan los grandes principios de la Mariología y devoción mariana. Pero además aumentan el mérito del libro la valentía, plasticidad y sentimiento emotivo de la exposición que dan calor humano y personal y sobrenatural, a esta obrita, una de las mejores producciones orozquianas. De lo que resulta no una seca exposición cerebral de la ascética mariana -no se lo permitía su talante de artista agustiniano y auténtico devoto de la Virgen-, sino una meditación jugosa, y así, en medio del discurso, prorrumpe tantas veces en exultaciones emocionadas de admiración o arrepentimiento, que dan el tono humano al estilo del Beato" 12 .

"Desde la aparición de las Siete Palabras, que fue la primera de las marianas, había ya publicado siete nuevas obras que eran acogidas con aceptación estimulante. Y, escritor mariano por vocación celestial, había de volver por su Señora, imprimiendo los sermones: 'quas in concionibus nostris ante annos triginta, Deo patrocinante, habuimus (1568)".

"Quería la divina Señora -dice su biógrafo P. Cámara-, que le ordenó predicase y escribiese, disfrutasen todas las edades de la doctrina que ella en alguna manera la inspiró; su capellán, por otro lado, entendiendo que el cielo le había confiado el Evangelio, no se complacía con predicar a una generación, sino anhelaba que todas ellas loasen a la sin par y bondadosa Virgen María" (2,3, p. 212)" ${ }^{13}$.

11. Alonso de Orozco, Confesiones lib. 3, IX. En obras III, Madrid 1736, p. 96.

12. Herran, L., Presentación de "Las siete palabras de Nuestra Señora del Beato Alonso de Orozco", Rialp, Madrid 1966, p. 24.

13. Herran, L., Presentación de "Las siete palabras de Nuestra Señora del Beato Alonso de Orozco", Rialp, Madrid 1966, p.17. 
Acerca de la obra "Comentaria quaedam in Cantica Canticorum" nos dice Laurentino Herran lo siguiente: "Trece años más tarde, 1581, Felipe Junt, impresor de Burgos terminaba el comentario del Beato, cuyo título completo es:

Commentaria quaedam in Cantica Canticorum, nunc denuo ex Doctorum dictis cogesta per fratrem Alphonsum ab Orozco augustinum. Accessere quadraginta quatuor annotationes in eadem cantica Mariae Virginis festivitatibus accomodatae.

Eran difíciles los tiempos en que el Beato publicaba sus comentarios. Fray Luis de León acababa de salir de la cárcel y una de las acusaciones, además de su traducción del Cantar, era su interpretación del mismo.

Pero la auténtica erudición bíblica, que ponía a salvo al beato Orozco y su devoción por el Cantar, que él se había hecho vida, tenía que exteriorizarse en un comentario concreto. Pues es de notar que raro es el libro en que no se cite y se comente este poema sin igual.

El Beato, siguiendo el simbolismo tradicional, expone a través de sus ágiles y lindas páginas los amores de Cristo y su iglesia. Y paralelos a estos amores los de Cristo con el alma en gracia" ${ }^{14}$.

"En el ocaso de su vida (1588) publicó su última obra mariana, la más importante sin duda: Tratado de la corona de Nuestra Señora, la cual fue con doce privilegios ensalzada...

Después de un prologuito al lector, expone el simbolismo de la señal que vio Juan (Ap 12), que, aunque se aplica directamente a la iglesia, también se entiende de María 'la mejor porción de la iglesia'. De su mérito literario baste escribir lo que el P. Nazario Pérez dice hablando de la primera estrella: 'no será difícil encontrar en castellano algunas demostraciones completas y menos sutiles del misterio de la Inmaculada, pero relámpagos de luz poética y aun largos y suaves resplandores como los que brillan frecuentemente en los escritos del Beato Orozco cuando habla de su misterio querido, no son fáciles de encontrar entre las arideces de una demostración teológica" ${ }^{15}$.

Es gratificante recordar aquí los sentimientos que Alonso de Orozco manifiesta en el momento de emprender la composición del Tratado de la corona de la Virgen Santísima. "Por dar algún consuelo a los devotos de esta reina celestial, y aun para mi ocupación, y devoción, quise escribir este libro, declarando aquellas doce estrellas, con que san Juan en su Apocalipsis vio coronada a esta Emperatriz de los ángeles: ya también va al fin doce oracio-

14. Herran, L., Presentación de "Las siete palabras de Nuestra Señora del Beato Alonso de Orozco", Rialp, Madrid 1966, p. 18, 19.

15. Ib., 20-21. 
nes a la misma Virgen Santísima, en las cuales suplicamos que nos gane de su Hijo y Señor nuestro gracia para imitar sus excelentes virtudes" ${ }^{16}$.

A lo largo del Tratado de la corona de Nuestra Señora Alonso de Orozco centra su atención y sus elucubraciones en la famosa señal aparecida en el cielo. Se trata de una mujer a punto de dar a luz un niño, vestida del sol, con la luna como pedestal y coronada con una corona de doce estrellas. He aquí el texto literal: "apareció entonces en el cielo una figura prodigiosa: una mujer vestida del sol, con la luna por pedestal y una corona de doce estrellas en la cabeza. Embarazada y a punto de dar a luz, los dolores del alumbramiento le arrancaban gemidos de angustia" (Ap 12,1-2). El libro de Alonso de Orozco va a ser una exposición del simbolismo de la corona de doce estrellas. Cada estrella le va a servir para hablar de un privilegio o de una gracia de María.

Podemos preguntarnos ahora por el modelo de exégesis, pues de esto se trata, que emplea Alonso de Orozco, a la hora de escribir su obra mariana. No resulta difícil responder al interrogante susceptible de hacerse. Una vez leído su libro, uno se da cuenta que Alonso de Orozco intenta sobre todo mover los corazones de sus lectores al amor a la Madre de Dios. Para ello se sirve fundamentalmente de la Biblia, pero vista menos técnicamente que alegóricamente. En su tiempo había cuatro formas de acercarse a la Palabra de Dios. Cuatro formas que respondían a cuatro sentidos, que, según se creía, poseía la Biblia. Helos aquí: 1) el sentido histórico o literal; 2) alegórico o cristológico; 3) tropológico, moral o antropológico; 4) anagógico o escatológico. Tales sentidos se hallan recogidos en estos versos latinos:

"Littera gesta docet; quid credas, allegoria;

moralis quis hagas; quo tendas, anagogia".

Durante el siglo XVI, que es el siglo en que escribe Alonso de Orozco, hay una tenue reacción a favor del sentido literal. Es una reacción contra el dominio exagerado del sentido espiritual. "Si pasamos a la Reforma y sus consecuencias inmediatas, vemos que con Cayetano, por parte católica, y con Lutero y Calvino, por parte protestante, se dio una reacción contra la tendencia alegorizante y una insistencia en el transfondo histórico de las obras bíblicas... Es interesante ver cómo las sectas disidentes del movimiento de la Reforma, los Anabaptistas y los Antitrinitarios, defendieron una exégesis espiritual, dado que algunos pasajes del AT. eran utilizados literalmente por la rama más conservadora de la Reforma como justificación bíblica para perseguir las sectas.

16. Alonso DE ORozco, Tratado de la corona de Nuestra Señora. Prólogo al lector. En . Obras III, p. 114. 
La Contrarreforma católica hubo de responder a los argumentos procedentes de la exégesis literal protestante, invocando también el sentido literal de la Escritura. El jesuita Maldonado (muerto en 1583) sacó a luz un importante comentario exegético. Sin embargo, una vez que pasó el peligro inmediato de la Reforma, volvió la exégesis espiritual" ${ }^{17}$.

Alonso de Orozco hace uso de este último modelo. Y se comprende, dada la finalidad de sus obras. Quiere, ante todo, promover en sus lectores una devoción intensa a María. Le interesa más mover los corazones que instruir las inteligencias. "Plegue a Nuestro Señor, que, con tal espíritu y deseo de aprovechar, leáis esta corona de Nuestra Señora, que merezcáis ser su imitador y en esta vida sirviéndo'?, para que en el cielo la merezcáis ver y gozar, sentada a la mano derecha de su precioso Hijo, nuestro Salvador Jesucristo" ${ }^{18}$.

Antes de entrar propiamente en la exposición, que hace en el Tratado de la corona de Nuestra Señora, Alonso de Orozco empieza recordando la doctrina de Agustín y otros Doctores de la iglesia sobre el significado de la frase del Apocalipsis que le va a servir de reflexión. No es otra que Apocalipsis 12,1-2. "Esta mujer es la santa iglesia romana, de la que el mismo san Juan dice: 'que la vio descender del cielo como esposa ataviada para su esposo' (Ap 21,2). Está bien dicho que del cielo descendió, porque allá tiene su fundamento, que es Cristo, el cual la sustenta, y la fabricó asimismo" ${ }^{19}$.

Al creer que María es la mejor pieza de la iglesia, después de Cristo, Alonso de Orozco acude a la imagen de la garganta, la parte más elevada del cuerpo, después de la cabeza, que, por supuesto, es Cristo. "El esposo en los Cánticos la comparó 'en su cuello a la torre de David, que estaba fuertemente edificada; en la cual estaban colgados mil escudos y toda la diferencia de armas de los animosos y fuertes' (Cant 4,4). El retrato es maravilloso, que nos da de su mano Jesucristo, su esposo. Contemplemos bien: así, en este cuerpo místico de Cristo, es la Virgen María la que hace ventajas a todos los santos, y aun a todos los celestiales espíritus. Por el cuello pasan los manjares, para sustentar la vida; por las manos y ruegos de la Virgen determinó Dios dar todas las mercedes al mundo. Vemos esto a la clara, pues el Padre eterno no dio su. Hijo para humanarse y redimirnos, sin que esta Señora de los Ángeles diese el sí, para ser madre de Dios... Por aquí entendemos, que, pues, don tan infinito, como es humanarse Dios, queriendo hacer de esta

17. Comentario bíblico San Jerónimo, Tom. IV. Estudios sistemáticos. Ed. Cristiandád, Madrid 1972, n 34-44, pp. 297-298.

18. Alonso DE OROzCo. Tratado de la corona de Nuestra Señora. Obras III. Madrid 1736, p. 114.

19. Alonso de OROZCO, Ib., 116. 
soberana Señora, se nos dio por su mano, que todo lo demás determinó el Señor que por ella se nos diese" ${ }^{20}$.

Alonso de Orozco habla aquí de uno de los títulos que ha tenido eco en la Mariología. Eco, por cierto, muy sobresaliente. Mediadora de todas las gracias. Sabemos por la Escritura que Jesucristo es el único mediador entre Dios y los hombres. "Porque hay un solo Dios y uno solo es mediador entre Dios y los hombres: el hombre Cristo Jesús" (1Tim 2,5). Esto es cierto. Y nunca hay que perderlo de vista. Ello no obsta para que participen de esta única mediación por gracia otras personas. Entre ellas ocupa lugar de excepción María. Y lo ocupa en razón de la misión que tuvo que llevar a cabo en el misterio de la Redención. El concilio Vaticano II escribe sobre el tema: "La bienaventurada Virgen María es invocada en la iglesia con los títulos de Abogada, Auxiliadora, Socorro, Mediadora. Lo cual, sin embargo, se entiende de manera que nada quite, ni agregue a la dignidad y eficacia de Cristo, único Mediador. Porque ninguna criatura puede compararse jamás con el Verbo encarnado nuestro Redentor; pero así como el sacerdocio de Cristo es participado de varias maneras, tanto por los ministros como el pueblo fiel, y así como la única bondad de Dios se difunde en formas distintas en las creaturas, así también la única mediación del Redentor no excluye, sino que suscita en sus creaturas una múltiple cooperación que participa de la fuente única.

La iglesia no duda en atribuir a María un tal oficio subordinado, lo experimenta continuamente y lo recomienda al corazón de los fieles para que, apoyados en esta protección material, se unan más íntimamente al mediador y Salvador" ${ }^{21}$.

El santo Concilio pone las cosas en su punto y sale al paso de un excesivo protagonismo concedido a María en el campo de la redención. Es la consecuencia normal de una buena teología, que hunde sus raíces, como lo tiene que hacer, en el mensaje de la Biblia. Esto por delante, tenemos que reconocer el acierto de Alonso de Orozco al dar a María el título de Medianera o Mediadora de todas las gracias. Con ello marca un camino seguido en multitud de ocasiones por el magisterio de la iglesia en la persona de los papas. Me parece oportuno en este momento recoger aquí algunos textos significativos papales sobre el tema. "Para curar, en efecto, las llagas sociales, no hay remedio más eficaz que la invocación de Aquella que, después de haber procurado la salvación del género humano por medio de su divino Hijo, mereció ser apellidada el poderosísimo Socorro de los cristianos ${ }^{22}$.

20. Alonso de Orozco, Tratado de la corona... Madrid 1736, 117.

21. LG a y b.

22. LEON XIII, Ep. apost. L'Eclatant, 10 de junio de 1903. En documentos Marianos, BAC, Màđrid 1954, n. 480, p. 357. 
"La consecuencia de esta comunidad de sentimientos y sufrimientos de María y Jesús es que María 'mereció ser reparadora dignísima del orbe perdido'. Y, por tanto, la dispensadora de todos los tesoros que Jesús conquistó con su muerte y con su sangre" ${ }^{23}$.

"La benignísima Virgen Madre de Dios sonreía favorablemente a estos nuestros deseos y conatos, la cual, habiéndonos dado y criado a Jesús Redentor, y ofreciéndole junto a la cruz como hostia, fue también y es piadosamente llamada Redentora por la misteriosa unión con Cristo y por su gracia absolutamente singular. En cuya oración ante Cristo confiados nos, que aun siendo el único Mediador de Dios y de los hombres (1Tim 2,5), quiso asociarse su Madre como abogada de los pecadores y administradora y medianera de la gracia..." ${ }^{24}$.

"Asociada, como Madre y ministra, al Rey de los mártires en la obra inefable de la humana redención, le queda para siempre asociada con su poder casi inmenso, en la distribución de las gracias, que se derivan de la redención" ${ }^{25}$.

"La iglesia sabe y enseña con san Pablo que uno solo es el mediador: 'Hay un solo Dios y también un solo mediador entre Dios y los hombres, Cristo Jesús, hombre también, que se entregó a sí mismo como rescate por todos' (1Tim 2,5-6). La misión maternal de María para con los hombres no oscurece ni disminuye en modo alguno esta mediación única de Cristo, antes bien, sirve para demostrar su poder: es mediación en Cristo.

La iglesia sabe y enseña que 'todo influjo salvífico de la Santísima Virgen sobre los hombres... dimana de los méritos de Cristo; se apoya en la mediación de éste, depende totalmente de ella y de la misma saca todo su poder" ${ }^{26}$.

No se puede pedir ni mayor densidad de pensamiento, ni mayor coherencia. Todos los textos, aquí recogidos, encabezados por el mensaje del concilio Vaticano II, manifiestan a las claras que la doctrina de Alonso de Orozco, al hablar de María como medianera, es una doctrina netamente eclesial. Alonso de Orozco se hace en ello fiel intérprete de la tradición de la iglesia. Naturalmente que la magnitud de un don como éste no debe hacernos olvidar que lo bonito, lo hermoso de María, lo grandemente evocativo y válido, es su vida sencilla y escondida entre las paredes de un hogar humilde. La fidelidad a la voluntad de Dios hecha carne viva en el quehacer rutinario y cansino del quotidiano vivir es lo que constituye la mayor grandeza de

23. S. PIo X. Ep. Enc. “Ad diem illum” 2-II-1904. En ib. n. 488b, p. 371.

24. Pro XI. Ep. Enc. Miserentissimus Redemptor, 8-V-1928. En Ib. n. 608, p. 450.

25. PIo XII. Radiomensaje: Bendito seia o Senhor, 13-V-1946. En Ib. n. 737b. p. 585.

26. JuAn Pablo II, Redemptoris Mater, Ed. Paulinas, Madrid 1987, n. 38a y b., p. 64. 
María. Así nos descubre un camino ancho y sereno por el que pueden caminar quienes lo deseen.

Al llegar aquí no me resisto a trascribir un texto, que considero admirable por el contenido y por el lenguaje. "Detengámonos unos momentos más en la figura de María, de esta doncella en la que Dios hizo grandes cosas, en la que acaba una edad del mundo y comienza otra. María, la más clara imagen de la expectación de Israel, se convierte en prototipo de la iglesia, que recibe a Jesús. Ella no tiene la misión de predicar, como la tuvieron Juan Bautista y los apóstoles. María no es un heraldo oficial. Así se explica que el Evangelio de Marcos, que trata solamente de la predicación pública de Jesús, le dedique poca atención. Pero Mateo, Lucas y Juan descubren progresivamente su misión. Ésta no consiste sólo en el parentesco de sangre con Jesús (cf. Lc 8,15-21); María está implicada con toda su persona en los acontecimientos. Ella guardó en su corazón las acciones salvadoras (cf. Lc 2,1955). Ella creyó (cf. 1,45). Concibió antes en su espíritu que en su carne” ${ }^{27}$.

III

Proclamada y reconocida la gracia de María como Mediadora, título no contemplado por Alonso de Orozco en la corona de las doce estrellas, pero perfectamente encajable en su doctrina, como así lo hace, sobre la figura de María, Alonso de Orozco comienza su exposición partiendo del texto ya citado de Apocalipsis 12,1-2. Lo hace usando el método exegético alegóricoedificante, muy propio de su tiempo. Con ello consigue la meta que se ha propuesto: cantar las gracias de María y promover su devoción entre sus lectores. Al fin y al cabo, él no escribe por escribir e instruir. Él escribe para poner al descubierto su amor a la Madre de Dios y, de este modo, llevar a otros el amor de María.

"Bendito sea el que, teniendo Padre en la eternidad, quiso tomar Madre temporal, para que, escogiendo él Madre para sí, nos enriqueciese a los hijos de Adán, dándonos tal Madre, tal Abogada y Señora tan bastante que pudiese sanar al enfermo, quitar los gemidos del género humano, medicinar y dar salud al hombre deshauciado y desconfiado de otro remedio alguno" ${ }^{28}$.

Alonso de Orozco ve en la primera estrella de la corona una imagen de la Inmaculada Concepción de María. Es normal. La concepción es el inicio de la vida. Y María se vio libre de pecado desde el momento de su concep-

27. Catecismo Holandés, Herder, Barcelona 1969, p. 80.

28. Alonso DE Orozco, Tratado de las siete palabras de María santísima, Rialp, Madrid, $1966,62-63$. 
ción. Así vio este misterio y así lo perfiló en su célebre carta apostólica el papa Pío IX, fechada el 8-XII-1954 y que tiene el título siguiente: Ineffabilis Deus. "Para honra de la santa e individua Trinidad, para gloria y prez de la Virgen Madre de Dios, para exaltación de la fe católica y aumento de la cristiana religión, con la autoridad de nuestro Señor Jesucristo, con la de los santos apóstoles Pedro y Pablo, y con la nuestra, declaramos, afirmamos y definimos que ha sido revelada por Dios y, de consiguiente, que debe ser creida firme y constantemente por todos los fieles, la doctrina que sostiene que la Santísima Virgen María fue preservada inmune de toda mancha de pecado original, en el primer instante de su concepción, por singular gracia y privilegio de Dios omnipotente, en atènción a los méritos de Jesucristo, Salvador del género humano" ${ }^{29}$.

Alonso de Orozco comienza así su exposición" “Queriendo ya comenzar a tratar de estas doce estrellas, o privilegios singulares, que a esta Señora del mundo se dieron, diremos que el primero fue ser concebida sin pecado original" ${ }^{30}$. Alonso de Orozco se entretiene en mostrar que la Madre de Dios tenía que ser limpia de todo pecado, incluido el llamado pecado original. "No hay mayor bajeza que pecar mortalmente, menospreciando la Ley de Dios. Luego debemos loar a nuestra Señora, porque su alma santa, (este lenguaje es tributo a la cultura de su tiempo), siempre fue libre de pecado, amiga de Dios; y que ni por un punto le tocó nuestra triste herencia, que nos viene de Adán" ${ }^{31}$.

El argumento de fondo para toda esta doctrina, usado por Alonso de Orozco, es ciertamente precioso y de gran calidad teológica. Se trata de la relación íntima, única de María con Jesús, su Hijo y Señor. Sabemos por la Escritura que el Hijo de Dios, hecho hombre, se hizo semejante en todo a nosotros, menos en el pecado (cf. $\mathrm{Hb} 4,15$ ). Ello se debe a su propia condición divina. A ser Hijo de Dios-Padre, igual en todo al Padre. La Biblia siempre ha presentado a Dios como santo. El santo por esencia. Y, por tanto, alejado sustancialmente de todo lo que se opone a la santidad: el pecado. Afirmar, por ejemplo, que en Dios hay o puede haber pecado es algo que no entra en el mensaje de los libros inspirados. Por eso, al hablar del Hijo de Dios hecho hombre, asemejado en todo a sus hermanos, los hombres, tiene que hablar de una excepción. Menos en el pecado.

29. Pro XII, Carta Apostólica Ineffabilis Deus, 8-XII-1954. En Documentos marianos, BAC, Madrid 1954, n. 299. p. 190-191.

30. Alonso DE OROzCO, Tratado de la corona de nuestra Señora. en obras III, Madrid, 1736, p. 117.

31. Alonso De Orozco, Tratado de la corona de nuestra Señora. en obras III, Madrid, 
Lo que a Jesús se le debe en razón de su condición divina se concede a María por gracia en razón de la misión que debía cumplir en el misterio de la Redención. María es la Madre de Jesús. En fuerza de esta realidad María tiene que estar libre de todo pecado. Llena de gracia la llama el mensajero de la Encarnación. Tan llena que en su espíritu no hay lugar para el pecado. María es así el primer fruto de la Redención de Jesús. Ella también es redimida. Pero redimida de forma distinta. Unos espléndidos versos en castellano expresan el misterio: "Ninguno del ser humano / como vos se pudo ver / que a otros los dejan caer / y después les dan la mano. Mas vos, Virgen, no caíste / como los otros cayeron / que siempre la mano os dieron / con que preservada fuiste". No hubiera sido honroso para el Hijo de Dios, que no conoció pecado, haber tenido una madre sometida al pecado. Alonso de Orozco habla de este tema en la forma que sigue: "Es tan conforme a razón haber gozado la Madre de Dios de este privilegio tan nuevo y tan grande que dice Salomón 'que la honra del padre consiste en que el hijo sea sabio' (Prov 10,1). Siendo, pues, en eternidad elegida esta Señora para Madre del Criador del mundo, y el Hijo, que para este efecto la crió, Sabiduría infinita y Poder no limitado, por la propia honra del Hijo de Dios había de guardar que su gloriosa Madre no tuviese mácula de pecado original" ${ }^{32}$.

La argumentación que usa Alonso de Orozco, se encuentra en la más pura línea agustiniana. En efecto, Agustín, el doctor de la gracia, afirma categóricamente: "Exceptuada, pues, la Virgen María, de la que no quiero entablar disputa alguna, cuando se trata de pecado y ello debido al honor del Señor..., todos los demás son reos de pecado... 'Si dijéramos que no tenemos pecado, nos engañamos a nosotros mismos y la verdad no está en nosotros'" ${ }^{33}$. Aunque no concuerdan los estudiosos de Agustín sobre si este su pensamiento acerca de la Madre de Dios se extiende hasta el pecado llamado de origen, hay que reconocer que los que están por la afirmación son más numerosos y tienen más y mayores razones a su favor. Las palabras de Agustín son absolutamente universales. No parecen poder dar ocasión a establecer una excepción.

El concilio de Trento, que definió la doctrina sobre el pecado original y que no consideró todavía oportuno definir el dogma de la Inmaculada Concepción, hace esta solemne declaración: "Declara, sin embargo, este mismo santo Concilio que no es intención suya comprender en este decreto, en que se trata del pecado original, a la bienaventurada e inmaculada Virgen María, Madre de Dios" ${ }^{34}$.

32. Alonso de OROZCo, Ib., 118.

33. SAN Agustin, De nat. et grat. 36,42; ML 44,267.

34. DeZINGER, E., El magisterio de la iglesia, N. 792b., p. 227. 
Esta gracia queda reservada para el Papa Pío IX. En efecto, el 8 de diciembre de 1954 el Papa Pío IX declara dogma de fe la doctrina que defiende la preservación de María del pecado original. Su texto oficial ha quedado citado líneas adelante.

Es de agradecer a Alonso de Orozco su doctrina acerca de la Inmaculada Concepción. Misterio que él ve reflejado en la primera estrella de la corona. Doctrina que se halla ya presente en el ambiente en que él se mueve. No en vano España es la abanderada de este misterio ya en el concilio de Trento. Alonso de Orozco se recrea usando calificativos de distinto signo, cuando habla del misterio. "Si queremos considerar qué cosa es pecado original, entenderemos con cuánta razón Dios preservó a su santa Madre, que no cayese en él. Éste es un mal tan g...nde, que parece no acaban los teólogos de darle su nombre. Llámanle mácula, astilla o yesca del pecado actual, enemistad con Dios y un desconcierto de casa. Mancilla es y tan fea, que con ser el alma una representación del que la crió, y criada a su imagen, la desconoce; y lo que es más, la aborrece, privándola de gloria celestial, para cuyo fin fue criada... Pues si la traición contra el rey terreno así se castiga (cuenta aquí Alonso el castigo de unos caballeros que se rebelaron contra el rey), la que Adán cometió contra Dios, en quien se puso, como en cabeza, la justicia original para él, y para sus hijos, ¿por qué no se castigará, no sólo en él, sino también en nosotros sus hijos? Ya tenemos que este pecado es mácula, que afea al alma.

Llámase también yesca de pecado actual. ¡Oh miserables nosotros! de esta yesca tan seca resulta el encendernos con poca ocasión de ira, envidia en toda manera de pecado. Masa de culpa somos, antes que nacidos. Tomamos esta triste posesión, como herederos legítimos, de aquel pecador Adán. Esto quiso decir David, confesando que en pecados había sido concebido por su madre'. Llama pecados a la culpa original, porqūe, aunque es uno, es raíz y manantial de todos los pecados. Dais con un eslabón en un pedernal, saltan centellas, y poniendo yesca, encendéis lumbre. Ved si de esta culpa saltan centellas y como yesca prenden en el alma, quedando inclinada para obrar cualquier maldad.

Finalmente, la culpa original es un desconcierto de casa. ¡Oh Santo Dios, qué reloj tan concertado y qué casa tan ordenada era Adán, cuando Dios le crió con la justicia original, que en él puso! La carne estaba sujeta al espíritu y el espíritu a su Criador. ¡Oh mayorazgo precioso! ¡Oh pérdida, qué poco la sentimos, porque nunca la poseímos! Perdió Adán la justicia original y quedó la casa desconcertada, siendo rebelde el cuerpo al espíritu, en pago que el espíritu, fue rebelde a su Criador. Esto lloraba con gran sentimiento san Pablo, escribiendo a los Gálatas: 'la carne desea contra el espíritu y el 
espíritu, contra la carne: esos andan en continua guerra'.... (Gál 5,17). Así andan el cuerpo y el alma luchando sin tener paz. Pues decidme: si es la culpa original mancilla tan fea, ¿cómo la había de consentir el Hijo de Dios en su Madre, de quien se había de vestir tomando carne? Y si es yesca de pecado actual, ¿a qué propósito esta Señora de los ángeles la había de heredar? Finalmente, si es un desconcierto de casa, luego en la Virgen jamás lo hubo, pues había de ser casa de paces, como estaba profetizado: 'Grande será la gloria de esta casa y en ella daré paz' $(\mathrm{Ag} 2,10)$. ¡Oh Virgen gloriosísima, o casa de Dios pacífica, donde se hicieron las paces entre Dios y los hombres, naciendo de Vos el figurado Rey, pacífico Salomón, nuestro Redentor Jesucristo" ${ }^{35}$. ¡Cruda descripción! ¡Incluso, inadecuada descripción en algunos aspectos del pecado original! Dios no puede odiar a nadie. Ni siquiera al pecador. "Amas a todos los seres y nada de lo que hiciste aborreces, pues, si algo odiases, no lo hubieras creado" (Sab 12,24). Seguramente que Alonso de Orozco quiere poner muy de relieve las crudas consecuencias del pecado en general y del original en particular. Por ello se excede en las expresiones y así impresiona al lector.

$\mathrm{Al}$ revivir aquí el pensamiento teológico de Alonso de Orozco sobre el pecado original, resulta imposible evadir el compromiso de dedicar algunas reflexiones al tema. La problemática del pecado original es hoy especialmente virulenta. Lo es en sí misma y lo es, particularmente, por el revestimiento cultural con que se ha hecho. Es difícil para el hombre de hoy, que ha descubierto el valor de lo personal y con ello el de la responsabilidad personal, aceptar una supuesta responsabilidad de algo que no ha hecho. De algo que ha hecho un supuesto primer padre de la humanidad: Adán. La narración mitológica del Génesis (3), que tiene que ver más con una teología del pecado que con la trasgresión de un precepto impuesto por la Divinidad, ha sido el soporte primero y principal de la doctrina acerca del pecado original. Ahí se apoya Pablo para dar las líneas maestras del tema, haciendo de Adán el hombre carnal y de Cristo el hombre espiritual. Adán es tipo de Cristo que, como es natural, se constituye en antitipo. Adán es la imagen del hombre pecador. Cristo, la del hombre reconciliado. Si por Adán, a causa del pecado, murieron todos, en Cristo, por la obra de su redención, todos vuelven a la vida. Oigamos la frase modélica: "Pues si por un hombre vino la muerte, también por un hombre viene la resurrección. Al compartir la nāturaleza de Adán, todos los hombres mueren; en cuanto injertados en Cristo, todos retornarán a la vida" (1Cor 15,21-22). Oigamos también el famoso texto de

35. Alonso De Orozco, Tratado de la corona de Nuestra Señora. en Obras III, Madrid $1736,119-120$. 
Romanos, puesto que es aquí en donde se apoyan los concilios, en concreto el II de Orange y Tridentino, para formular su enseñanza sobre el pecado original: "Por tanto, como por un hombre entró el pecado en el mundo y por el pecado la muerte y así la muerte alcanzó a todos los hombres, por cuanto todos pecaron". $(5,12)$. Este texto merece el siguiente comentario: "El pecado habita en el hombre, Rom 7,14-24; mas como la muerte, castigo del pecado, ha entrado en el mundo a consecuencia del pecado de Adán, Sb 2,24, Pablo deduce que el mismo pecado ha entrado en la humanidad por medio de esta falta inicial; es la doctrina del Pecado Original que interesa aquí al Apóstol 'por el paralelismo que le ofrece entre la obra nefasta del primer Adán y la reparación sobreabundante del último Adán', vv. 15-19; 1Cor $15,21 \mathrm{~s} ; 25 \mathrm{~s}$. Cristo salva a la humanidad, lo hace como nueva cabeza del linaje. Imagen según la cual restaura Dios su creación, Rom 8,29; 2Cor 5,17" ${ }^{36}$. Al terminar de leer esta nota, se queda uno con un cierto mal'sabor de boca. Parece una formulación excesivamente tradicional, siendo así que las investigaciones modernas autorizan para hablar del pecado original de otra forma.

Entrando ya de lleno en el tema del pecado original, es necesario recoger aquí el famoso texto del Concilio de Trento que consagra, por así decirlo, la doctrina de la iglesia acerca del tema. "Si alguno afirma que la prevaricación de Adán le dañó a él solo y no a su descendencia; que la santidad y justicia recibida de Dios, que él perdió, la perdió para sí solo y no también para nosotros; o que, manchado él por el pecado de desobediencia, sólo transmitió al género humano la muerte y las penas del cuerpo, pero no el pecado que es la muerte del alma: sea anatema, pues contradice al Apóstol que dice: 'por un solo hombre entró el pecado en el mundo, y por el pecado la muerte, y así a todos los hombres pasó la muerte, por cuanto todos habían pecado' (Roma 5,12)" ${ }^{37}$.

Algo hay en esta traducción, que ofrece Dezinger, de la doctrina del concilio de Trento sobre el pecado original, que llama la atención. Es su último inciso: "por cuanto todos pecaron". El autor se presenta aquí más movido por los datos de la investigación moderna que por la fidelidad al pensamiento del Concilio. En efecto, el Concilio hace referencia al texto paulino tal y como se encuentra en la traducción latina. Traducción que debe responder al 'in quo' y no al propter quod, como aquí acontece. Trento habla de Adán y de su pecado, trânsmitidô àl resto del género humano, porque todos pecaron en él y con él. Éste es el genuino pensamiento de Trento, recibido de Agustín y consagrado ya por concilios anteriores, entre otros el Concilio II

36. Biblia de Jerusalén, nota a 5,12 de Romanos.

37. Concilio de Trento. DeZINGER, E., n. 789, p. 225. 
de Orange (39). La traducción, que responde al pensamiento de Trento es, por consiguiente, ésta: en el que todos pecaron y no porque todos pecaron.

Así piensa Agustín, principal expositor del pensamiento paulino en casi todo, pero particularmente en el tema del pecado original. He aquí un texto paradigmático. "Dice el Apóstol: 'por un hombre entró el pecado en el mundo, y con o por el pecado la muerte; y así pasó a todos los hombres, en el que todos pecaron'. Si yo dijere esto, se pondrían de uñas los pelagianos y clamarían que no estoy hablando correctamente, que no siento rectamente. No entenderían, por tanto, en estas palabras sentencia de cualquier hombre, a no ser ésta que no quieren entender en el Apóstol. Pero, porque son sus palabras, a cuya autoridad y doctrina sucumben, a mí me achacan rudeza en el entender, cuando las cosas que tan claramente están dichas, intentan deformarlas en no sé qué. 'Por un hombre, dice, el pecado entró en el mundo, y por el pecado, la muerte'. Esto es propio de la propagación y no de la imitación: si se tratara de la imitación, debería decir por el diablo. Lo que no se puede poner en tela de juicio que aquí se trata de este primer hombre quien es llamado Adán. Y así, dice, que pasó (la muerte y con ella el pecado) a todos los hombres" ${ }^{38}$. Claro y contundente es Agustín en un texto en el que aborda directamente la doble expresión in quo y propter quod y se decanta abiertamente por la primera. "Tratáis de buscar (se refiere a los pelagianos) un otro sentido nuevo y torcido y os esforzáis en plasmar algo que se aparta de la verdad en las palabras del Apóstol 'por un hombre entró el pecado en el mundo y por el pecado la muerte; y así pasó a todos los hombres, en el que todos pecaron'. Y esto lo hacéis no sólo con descaro llamativo, sino, incluso, con demencia, oponiéndoos así a una fe solidísima. Afirmáis que las palabras en 'el que todos pecaron' se pueden entender como 'porque todos pecaron'..., de forma que no se entiendan en su sentido original, que no es otro que en un solo hombre todos pecaron. $Y$, en consecuencia, el pecado es común por la unidad de la masa, es decir, porque pecó el primero de los hombres, de forma que tal pecado se contrae por propagación y no por imitación. Vuestra interpretación (habla siempre con los pelagianos) no responde al sentido de las palabras del Apóstol, al cambiar el 'en el que por porque todos'" ${ }^{39}$. Según los textos citados Agustín, si viviera hoy, no aceptaría la traducción que se ofrece del texto paulino. Para Agustín sólo responde al pensamiento paulino el 'en el que' y no el 'porque todos'. Lo más grave de esta cuestión es que Agustín canalizó toda la reflexión occidental sobre el tema del pecado original, hasta el extremo de que el mismo

38. SAn Agustín, De pec. mer et rem. I, 10,10, ML 44, 115.

39. San Agustín, Cont. Jul. VI, 24,75; ML 44, 888. 
magisterio de la iglesia y, en concreto el concilio de Trento, lo entendió al modo agustiniano.

Todo esto nos indica lo complicado del problema que tenemos entre manos. El pecado original o, si se quiere mejor, la doctrina del pecado original es hoy insostenible tal y como está formulada tradicionalmente. Es preciso someterla a interpretación. Recojamos de entrada una exposición austera, aunque con matices todavía impropios de nuestro tiempo, del tema del Concilio Vaticano II: "Creado por Dios en la justicia, el hombre (ya no dice Adán), sin embargo, por instigación del demonio, en el propio exordio de la historia abusó de su libertad, levantándose contra Dios y pretendiendo alcanzar su propio fin al margen de Dios. Conocieron a Dios (pasa ahora del singular al plural), pero no le glorificaron como a Dios. Oscurecieron su estúpido corazón y prefirieron servir a la criatura, no al Creador. Lo que la revelación divina nos dice coincide con la experiencia" ${ }^{40}$.

Para poder encontrar un camino transitable y, de este modo, ofrecer una explicación, si no completa, sí al menos respetuosa con la investigación moderna acerca del origen del hombre, se necesita distinguir bien entre núcleo del mensaje y formulación del mismo. Éste es el camino que nos presenta el famoso Catecismo Holandés y cuyas líneas maestras voy a recordar aquí. Dicho Catecismo se fija en los dos textos bíblicos que han dado origen a la doctrina del pecado original. Son Génesis 3 y Romanos 5. En el primer caso amplía su punto de vista y se fija en los 11 primeros capítulos. Fácilmente se adivina que dichos capítulos son unos capítulos muy especiales. Se equivocaría de plano a plano quien intentara encontrar aquí una historia de la humanidad primitiva en el sentido técnico de la palabra. Su autor no tenía preparación para este cometido. Y la inspiración no suple estas lagunas. Tales capítulos se entretejen de narraciones de carácter eminentemente popular sobre Adán, a quien se considera cabeza de la humanidad; sobre Caín y Abel, en cuyo recuerdo aparece una de las manifestaciones más violentas del pecado; sobre Noé, cuya descendencia se constituye en salvación de una humanidad arruinada por el diluvio y sobre la construcción de la torre de Babel, un ejemplo palpable de hasta dónde puede llegar la insolidaridad humana.

Para el tema del pecado original en concreto hay que fijarse en el capítulo 3, en donde se narra, en un estilo plástico y popular, la caída de la pareja humana y sus lamentables consecuencias para su posteridad. Ya aquí aparece una realidad que será compañera inseparable de la historia de la salvación. Me refiero al mensaje del v. 15. El autor pone en boca de Yahvé las

40. GS 13a. 
siguientes palabras: "Pondré enemistad entre ti y la mujer y entre tu linaje y su linaje: él te pisará la cabeza, mientras acechas tú su calcañar" (Gen 3,15). En estas palabras han visto la mayoría de los Padres de la iglesia, y con ellos la iglesia misma, un anuncio de salvación, un proto-evangelio. Con lo que se indica bien a las claras cuáles son los designios de Dios sobre el hombre. A pesar de sus pecados y por encima de sus pecados Dios sigue su obra salvífica, ofreciendo al hombre la posibilidad de salvarse.

Después de recordar el relato de la caída del hombre, tal y como la presenta el capítulo 3 del Génesis y tras hacer algunas matizaciones del carácter de los 11 primeros capítulos del libro de "los orígenes", podemos hacer una pregunta. Debemos, más bien, hacerla. “¿Qué valoración merece todo esto y qué mensaje se esconde en sus páginas?". Sabemos que no se trata aquí de escribir hechos históricos aislados. La intención es más profunda. Mediante relatos simbólicos se describe el meollo de toda la historia de la humanidad, incluida la del porvenir. Adán es el hombre; Caín lo podemos ver en el periódico y tal vez vivo en nuestro propio corazón; Noé y los constructores de la torre de Babel somos nosotros mismos.

En los capítulos 1-11 describe el Génesis los elementos fundamentales de toda vida...

1. Dios crea y da el crecimiento, como lo proclaman el poema de la creación (Gen 1) y las grandiosas genealogías, que no deben tomarse al pie de la letra.

2. Muéstrase que el hombre está destinado a la amistad con Dios, como lo da a entender la historia del paraíso terrenal (Gén 2).

3. El tercer elemento es el pecado humano. Por amarga experiencia propia, hubo de conocer y re-conocer Israel esta constante de la historia humana. Por cuatro veces describe una caída la historia primitiva: la comida del fruto prohibido, el fratricidio, la corrupción de los acontecimientos de Noé y la construcción de la torre de Babel. Éstos son actos simbólicos de nuestros grandes pecados.

4. Pero Dios no deja al hombre solo. Ya en Israel se muestra incomprensiblemente misericordioso. Lo mismo dan a entender las historias primitivas. A cada caída sigue una manifestación de gracia...

La historia primitiva es un mensaje eterno sobre los más profundos elementos de nuestra vida en Dios: 1) La creación; 2) la elección; 3) el pecado; 4) la redención" ${ }^{41}$.

Si Génesis 1-11, especialmente Génesis 3, necesita de interpretación con el fin de captar más genuinamente su mensaje, otro tanto hay que decir de Romanos 5, en donde Pablo "pone los fundamentos más sólidos de la doctri-

41. Catecismo. Holandés, Herder, Barcelona 1969, 252s. 
na sobre el pecado original. Pablo está convencido de que la salvación es gracia. Es don de Dios. Que esa salvación le viene al hombre sólo por la obra de Jesucristo. Si hay algo que tenga una formulación clara en Pablo es "precisamente esto: que Cristo es el Salvador de los hombres". Ningún otro puede salvarnos, dice Pedro en los Hechos, pues en la tierra no existe ninguna otra persona a quien Dios haya constituido autor de nuestra salvación" $(4,12)$. Pablo participa plenamente de su mensaje. A la hora de articular este mensaje en su carta a los Romanos (5). Pablo se sirve de una tipología que, dados los conocimientos de su tiempo, le servía de forma admirable. La tipología se sustenta sobre Adán, padre y tipo de la humanidad vieja, y Cristo, padre y antitipo de la nueva humanidad. Adán, para Pablo persona de carne y hueso, ha traído con su pecado la muerte a todos los hombres. En él todos han pecado y todos han muerto. Cristo, con su obediencia hasta la muerte, trae la reconciliación, es decir, la superación del pecado y la vida a todos los hombres. Y ello con sobreabundancia. Cuanto más creció el pecado, tanto más abundante fue la gracia de Dios. Así como el pecado trajo el reinado de la muerte, así también será ahora la gracia la que reine por medio de Jesucristo, Señor nuestro, restableciéndonos en la amistad de Dios en orden a la vida eterna" ( $\mathrm{Rm}$ 5,20b-21).

Lógicamente, el mensaje de Pablo sigue siendo válido para el hombre de fe. Pero la forma, en que él lo transmite, puede y debe ser objeto de re-interpretación. De este modo, la fe o el depósito de la fe va encontrando formulaciones que estén de acuerdo con las inquietudes de los tiempos. Por eso, podemos y debemos preguntarnos por el mensaje paulino. ¿Qué es lo que Pablo, ministro de la revelación, quiere transmitir al hombre como palabra de Dios? Articulamos la respuesta con palabras del ya citado Catecismo Holandés. "En el nuevo testamento se ve aún más claramente que el mensaje de Dios contiene estos elementos. (Se refiere a los elementos de que había hablado al interpretar Génesis 1-11). Pero es sobre todo Pablo, quien en el capítulo 5 de la carta a los Romanos, nos lo presenta en toda su profundidad. A primera vista parece como si este pasaje quisiera acentuar ante todo el hecho de que el pecado entró en el mundo por un solo hombre. Pero esta repetición constante, como de un eco, de la palabra uno en que Pablo partía de la imagen contemporánea del mundo, es mera forma literaria, no el mensaje en sí mismo. Lo que este trozo, de difícil interpretación, quiere expresar es hasta qué punto reina en la humanidad el pecado juntamente con la muerte y hasta qué punto ha sobreabundado la gracia, la reparación justamente con la vida eterna, al venir Jesús al mundo...

El pecado original es el pecado de la humanidad en conjunto (incluido yo mismo), en cuanto afecta a todo hombre. En todo pecado personal resuena como acorde fundamental el pecado original... 
¿Cuál es, en suma, el mensaje de Dios contenido en este capítulo? Únicamente el mensaje bíblico: 1. El género humano fue creado por Dios. 2. Fue llamado a una íntima participación de su vida. 3. Culpable en su totalidad y solidariamente no corresponde a los designios de Dios. 4. Dios quiere liberarnos y sanarnos. Su salvación es restablecimiento, restauración.

Hemos expuesto este mensaje de acuerdo con nuestra actual visión del mundo: un mundo en crecimiento y evolución. Como el autor bíblico anunció el mensaje de acuerdo con su visión del mundo, así lo hacemos hoy nosotros de acuerdo con la nuestra. Lo cual es posible, pues en ambos casos se trata del mismo mensaje, de los mismos cuatro elementos, del mismo misterio divino, que nos ha sido revelado" ${ }^{42}$.

Ciertamente estamos ante un misterio. Se nos acaba de recordar. Y los intentos de explicación, aunque dignos de encomio y necesarios, se quedan en intentos. Se trata del esfuerzo legítimo de la mente humana por penetrar en el conocimiento de lo que cree. Por más que se arroje luz siempre quedará una gran zona de oscuridad. Con todo, hay que saludar con gozo que teólogos competentes se arriesguen a andar por caminos difíciles y no transitados. La teología no tiene por qué ser una ciencia sin más del pasado. No tiene por qué terminar siendo arqueología. Cierto que no puede perder de vista la Tradición y el magisterio de la iglesia. Esto supuesto, la teología debe intentar, con respeto y fidelidad, encontrar formas de lenguaje que respondan más y mejor a las inquietudes y avances científicos de una época determinada. Sólo así es algo vivo. Y sólo así puede ser acogida por el hombre.

Alonso de Orozco, presente en toda esta disertación, termina su interesante discurso sobre la Concepción Inmaculada de María, que él ve reflejada en la primera estrella de la corona, con una bella oración. He aquí parte de la misma: "Ea, Señora, Paloma sin hiel de ira, ni soberbia, Paloma única, y pura, más graciosa que aquella de Noé, que volvió con ramo de olivo, para declarar que ya el diluvio era acabado y la ira de Dios se había amansado: Vos nos trajisteis a la tierra la oliva fructífera, que es a Dios humanado, por cuya venida la justicia del Padre se amansó y de Dios de venganzas, fue hecho Padre de misericordias... Sin ser rogada en las bodas de Caná fuisteis intercesora para que la falta de vino milagrosamente se remediara. Esta falta

42. Catecismo Holandés, Herder, Barcelona 1969, p. 253ss. Tal vez alguien puede extrañarse de estas últimas citas del Catecismo Holandés, precisamente en un tema que fue objeto de matización por parte de una Comisión de Cardenales. Tengo ante los ojos el texto cardenalicio y puedo decir que reproduce las líneas de base del Catecismo. A ellas añade matizaciones de carácter eminentemente tradicional. Con ello el texto cardenalicio más que interpretar lo que hace es repetir. Aquí se trata de la reinterpretación de una doctrina que crea problemas a la mentalidad moderna. Ello lo hace de forma respetuosa con el dogma el Catecismo Holandés. 
de amor a Dios y del prójimo hay en mí. Humildemente os suplico que pidáis a vuestro Hijo precioso, tenga por bien de darme lágrimas de contrición, deseos afectuosos para servirle, fortaleza para perseverar, perseverancia para siempre alabarle y dar gracias" ${ }^{43}$.

La escasez de espacio impide seguir la exposición de Alonso de Orozco paso a paso. Es necesario hacer una selección, que tenga en cuenta la edificación del creyente. Se ha hablado de la Inmaculada Concepción de María, representada en la primera estrella. Ciertamente el mensaje de esta gracia extraordinaria es instructivo. Todo creyente tiene ante sí una tarea que debe realizar ayudado de la gracia de Dios: luchar contra el pecado. Se trata de una tarea permanente. El pecado es semejante a la mala hierba. Nace constantemente, aunque uno no sabe cómo. Es preciso arrancarla. $Y$ hay que hacerlo, para así poder ser instrumentos dóciles en las manos de Dios. María, limpia por gracia de todo pecado, es un buen punto de referencia. Es verdad que ello puede engendrar en nosotros, sometidos al imperio del pecado, un cierto dejo de indiferencia. En concreto, María estaba de tal manera equipada que prácticamente no podía pecar. Lo que no acontece con nosotros, que más bien estamos sujetos al imperio del pecado, hasta el extremo que tenemos que reconocer como realidad de nuestra vida, so pena de hacer pasar por mentiroso a Dios. (Cf. 1 Jn 1;10). A pesar de todo, ver a María libre de todo pecado es un buen estímulo para que nosotros luchemos contra el pecado. El pecado no es tanto una falta moral, una rebeldía contra la voluntad amorosa de Dios. El pecado es, sobre todo, deshonra y rebajamiento del mismo ser humano. "Al negarse con frecuencia a reconocer a Dios como su principio, rompe el hombre la debida subordinación a su fin último y también toda su ordenación, tanto como por lo que toca a su persona como a las relaciones con los demás y con el resto de la creación.

Es esto lo que explica la división íntima del hombre. Toda la vida humana, la individual y la colectiva, se presenta como una lucha, y por cierto dramática, entre el bien y el mal, entre la luz y las tinieblas. Más todavía, el hombre se nota incapaz de domeñar con eficacia por sí solo los ataques del mal, hasta el punto de sentirse como aherrojado entre cadenas. Pero el Señor vino en persona para liberar y vigorizar al hombre, renovándole interiormente y expulsando al príncipe de este mundo (Jn 12,31), que le retenía en la esclavitud del pecado. El pecado merma al hombre, impidiéndole lograr su propia plenitud.

43. Alonso DE ORozco, Tratado de la corona de Nuestra Señora. En Obras III, Madrid $1736,122-123$. 
A la luz de esta revelación, la sublime vocación y la miseria profunda, que el hombre experimenta, hallan simultáneamente su última explicación" ${ }^{44}$.

\section{IV}

Paso ahora a la quinta estrella de la corona. Alonso de Orozco ve en ella el don del Espíritu Santo. Comienza el Beato su exposición de la forma siguiente: "El Espíritu Santo vendrá sobre Vos, Virgen santa'. Respuesta es que el Ángel san Gabriel dio a Nuestra Señora, la cual le preguntó la manera, que se había de tener, para ser madre, sin detrimento de su virginidad" ${ }^{45}$.

Alonso de Orozco se recrea en diversas consideraciones sobre la conveniencia de que el Hijo de Dios naciera de una mujer. Dios ciertamente pudo haber hecho las cosas de otra manera. Pero quiso que su Hijo naciera de una mujer y, de este modo, se asemejara lo más posible a los hombres. Todos los hombres han tenido una madre. El Hijo de Dios no quiso seguir otro camino. Alonso de Orozco apoya esta opción en una frase del libro de la Sabiduría: "Dios toca de un fin hasta otro fin fuertemente y ordena todas las cosas suavemente" $(8,1)$. Estas palabras le sugieren a Alonso de Orozco el siguiente comentario: "Es poderoso y todo lo puede. $\mathrm{Y}$ con todo eso toma medios dulces para hacer sus obras. ¡Oh lo que debemos a nuestro Dios, en disponer con tanta dulzura el negocio grande de nuestra redención! Lo ordinario es, y así lo quiso él, que los hombres nazcan de una mujer; y, por tanto, quiso, por su clemencia, elegir madre y nacer de mujer; mas como tenía Padre en eternidad, Dios como él, no quiso padre en la tierra, como todos lo tenemos, sino solo madre y ésta Virgen pura, como en el capítulo pasado dijimos" ${ }^{46}$.

En relación con el tema, que estoy tratando, no se puede por menos de traer aquí uno de los pasajes más bellos de la Biblia. Bello, por la sobriedad y la profundidad teológica y el mensaje que contiene. Pablo, recordando la obra del Hijo de Dios, hecho hombre, escribe en su carta a los Gálatas: "Al llegar el momento cumbre de la historia, Dios envió a su Hijo, nacido de una mujer (¡maravilloso!), nacido bajo el régimen de la Ley, para liberarnos del yugo de la Ley y alcanzarnos la condición de hijos adoptivos.

Y prueba de que sois hijos es que Dios ha enviado al Espíritu de su Hijo a vuestros corazones. Y el Espíritu clama: ¡Abba, Padre! Eres, pues, hijo y no esclavo" (4,4-7a). ¡Hermoso mensaje y bellas palabras! Ello y ellas me

44. GS $13 \mathrm{a}$, b y c.

45. Alonso DE ORozco, Tratado de la corona de Nuestra Señora, en Obras III, Madrid $1736,137$.

46. Alonso de Orozco, Ib., 138. 
sugieren el siguiente comentario, que servirá para descubrir la presencia del Espíritu en la obra de la Encarnación. En efecto, la filiación, que Dios nos ha regalado en su Hijo, es proyección y reflejo de la filiación del Hijo de Dios. ¡Somos hijos en el hijo! Pablo nos dice en Gálatas 4 que somos hijos y podemos llamar a Dios ¡Abba, Padre! Y ello, porque Dios nos ha donado el Espíritu de su Hijo, que es Espíritu de filiación. Es decir, nuestra filiación es obra del Espíritu.

Ello nos hace entender que en la Encarnación del Hijo de Dios, raíz de nuestra filiación, sucede lo mismo. El Verbo de Dios toma carne en las entrañas de María y lo hace no por voluntad de varón, sino en fuerza de la acción el Espíritu Santo. Las palabras, que oye María de boca del ángel, 'El Espíritu Santo vendrá sobre ti y el poder del Altísimo te cubrirá con su sombra. Por eso, el niño que ha de nacer será santo, será Hijo de Dios' (Lc 35b36), adquieren nueva perspectiva a la luz del mensaje de Gálatas. La encarnación, por ser el misterio fontal de toda la obra salvífica, es también, al mismo tiempo, la obra más grande de amor. Por la encarnación Dios ha hecho por el hombre lo que éste ni siquiera podía imaginar. Entendemos, puestos en este punto de vista, que el evangelio de Juan tenga la audacia, se necesita ciertamente audacia para ello, de poner en boca de Jesús las siguientes palabras: "Tanto amó Dios al mundo, que no dudó en entregarle a su Hijo único, para que todo el que crea en él no perezca, sino que tenga vida eterna" $(3,16)$.

De ahí que la encarnación esté pidiendo a gritos la actuación del Espíritu Santo. Es ininteligible sin tal actuación. Y lo es en razón de su ser-amor. También, al ser la raíz primera de nuestra condición de hijos de Dios. Hay aquí una razón más profunda de lo que, a primera vista, pueda parecer y lo que la siempre concepción virginal exige. El Espíritu Santo tiene que estar presente en la encarnación y ser su causa primera, porque la toma de carne humana por el Hijo de Dios es el acto de amor divino más grande y la fuente de vida más abundosa. En la encarnación se inicia la nueva humanidad, la gran familia de los hijos de Dios. Al hacerse nuestro hermano, tomando la condición de hombre, nos hace hijos de Dios, es decir, nos hace dioses. Dios se hace hombre, para que el hombre se haga dios. Es una bonita expresión y un resumen estupendo de la obra de la encarnación y de la actuación del Espíritu Santo en ella. Somos hijos en el Hijo, pero por la obra del Espíritu de adopción.

Todo esto supera con mucho el mero marco o ámbito de lo biológico, en el que tal vez se ha insistido demasiado. El Hijo de Dios, hecho hombre, es un don tan fuera de las previsiones humanas, que no se puede explicar por ninguna ley natural. Sólo el Espíritu Santo puede ofrecer la clave para des- 
cubrir la inmensidad del don divino dado en la encarnación del Hijo de Dios. "Porque el Espíritu Santo es amor del Padre y del Hijo, que por vía de amor, amándose, le inspiran, dice el ángel, que el Espíritu Santo vendrá sobre la Señora del mundo, y como hacerse Dios hombre fue obra de tan maravilloso amor, está bien dicho que el Espíritu Santo scrá el que ha de sobrevenir. ¡Oh soberana fe, que todas grandezas nos enseñas! Con razón la llamó el Apóstol 'don de Dios que no puede ser merecido por méritos humanos' (Ef 2,3)" ${ }^{47}$.

Leyéndole, se nota que Alonso de Orozco siente verdadera fruición escribiendo sobre el misterio de la encarnación y la virginidad de María. Alonso de Orozco deja traslucir un verdadero gozo, al contemplar desde la fe que la obra de la encarnación es obra de amor. Y, como tal, debe ser obra realizada por la actuación del Espíritu Santo. No extraña, por tanto, que sea aquí en donde él recuerda el texto del evangelio de Juan antes citado. Extasiado en la contemplación del misterio, abre su corazón y deja salir sus profundos sentimientos. "Aquí se manifiesta ser obra de amor la Encarnación, pues el Padre, amando nuestro remedio, nos dio su mayorazgo Único Hijo, para que, hecho hombre, remediase todo el linaje humano. Muy bien dijo san Dionisio (=Pseudo-Dionisio): 'el amor saca de sí mismo al amante'. ¡Oh cuán lejos de sus condiciones hallaremos a Dios humanado! El eterno nace temporalmente y le van contando los días, y los años; el que sustenta al mundo, es alimentado de la leche virginal de su santa Madre. Finalmente, el inmortal padece trabajos y muerte. Bien lo entendió Isaías, cuando dijo: 'para hacer su obra, se hizo peregrino, y en su obra se manifestó extraño' $(28,21)$. ¿Qué obra es la que hizo viniendo al mundo, sino reparar al hombre, que había criado a su imagen y semejanza, que estaba estragada (=corrompida)? ¿Qué obra extraña hizo para salir con tan gran demanda, sino que, siendo Señor, se hizo siervo. Y, siendo el que manda a las Jerarquías del cielo, se sujetó a la obediencia de su santa Madre, y de José, criaturas suyas?" ${ }^{48}$.

Encendido en amor a María, Alonso de Orozco termina sus reflexiones sobre esta gracia concedida a María con una ardorosa invocación. “ $\mathrm{OH}$ templo vivo del Espíritu Santo, no de piedras muertas como aquél (el de Salomón)! ¡Oh cielo empíreo y paraíso fabricado de la mano del inmenso Dios! Los ángeles y santos os miran y admirándose dicen: 'no se ha hecho en el cielo, ni en la tierra tal obra, tan primorosa y tan admirable! $¡$ Oh vaso prodigioso! ¡Oh obra singular, que la sabiduría divina ha obrado por la gran abundancia de gracia y de virtudes, que el Señor en vos puso! Suplícoos me

47. Alonso DE OROzCO, Tratado de la corona de nuestra Señora. En Obras III, Madrid 1736, p. 138.

48. Alonso DE OrOzCo, Tratado de la corona de nuestra Señora. En Obras III, Madrid 1736 , p. $138-139$. 
ganéis del Señor, que tanto os sublimó, que yo pecador alcance perdón de mis pecados y me dé su gracia, para que dignamente le sirva" ${ }^{49}$.

Tales expresiones, escritas en un tono un tanto empalagoso y melifluo, pueden producir una cierta sensación de desagrado. No es correcta esta reacción. Alonso de Orozco está intensamente enamorado de María. Y, cuando se da una circunstancia como ésta, se usan los términos más extraños y desorbitados, a fin de intentar expresar lo mejor posible lo que late en el fondo del corazón.

Los cristianos hemos sido elegidos y con-vocados para ser santos. "Todos, en la iglesia, ya pertenezcan a la jerarquía, ya pertenezcan a la grey, son llamados a la santidad, según aquello del Apóstol: 'porque ésta es la voluntad de Dios, vuestra santificación' (1Tes 4,3; cf. Ef 1,4)".

La santidad, a la que hemos sido con-vocados, no es posible sin el ejercicio intenso de las virtudes llamadas teologales: fe, esperanza y caridad. Son núcleo, porque en su ejercicio se encuentra la santidad cristiana. La fe nos abre el camino de Dios. "Sabemos que sin fe es imposible agradarle (a Dios). En efecto, para acercarse a Dios es preciso creer que existe y que no dejará sin recompensa a aquellos que le buscan" (Hb 11,6). La esperanza nos sitúa de tal manera en la cercanía de Dios, que éste llega a ser el supremo objeto de nuestras aspiraciones, hasta el extremo de brotar una nueva luz que da un nuevo y preciso retrato de las cosas. La esperanza, presente ya aquí, rompe el cerco del horizonte terreno y proyecta su luz al infinito. "Porque salvados ya lo estamos, aunque sólo en esperanza. Sólo que esperar lo que uno tiene ante los ojos no es propiamente esperanza, pues ¿cómo seguir esperando lo que ya se tiene ante los ojos? Pero si esperamos algo que no vemos, entonces ponemos en juego nuestra esperanza" (Rom 8,24-25). "Pablo, servidor de Dios y apóstol de Jesucristo para hacer que los elegidos de Dios lleguen a la fe y al conocimiento de la verdad manifestada en un culto viviente y apoyada en la esperanza de la vida eterna.

Dios, que no miente, prometió esa vida antes que el tiempo existiera; y ahora, en el tiempo prefijado, ha hecho público su mensaje mediante la predicación que a mí me ha sido confiada por mandato de Dios, nuestro Salvador" (Tit 1,1-3). La caridad, reina de las virtudes y esencia de la santidad,

49. Alonso DE OROzCo, Tratado de la corona de nuestra Señora. en Obras III. Madrid $1736,141$. 
hace posible la unión Dios-Trino. Por ella le amamos. En cierta manera, salvando la identidad, nos identificamos con él. "Dios es amor" (1Jh 4,16). Por eso, la caridad nos hace dioses. Por ella se hace vivo aquello que dice el Génesis: el hombre está a imagen y semejanza de Dios (cf. Gén 1,26-27).

El cristiano debe "asegurar y mantener en su existencia la vitalidad teologal. ¿Qué entendemos por vitalidad teologal? Hacer que persista en nosotros, de una manera más o menos consciente, la fe en Dios y la visión sobrenatural del mundo y de las cosas, el ágape que nos constituye en Dios y en Él nos hace amar al prójimo, la esperanza y la espera del orden definitivo, en que estamos ya establecidos por la gracia, etc.; en suma, todo lo que se llama vida teologal ${ }^{50}$.

En fuerza de todo esto, y además como consecuencia de la misión que María cumplió en el misterio de Cristo, la Virgen tuvo que alcanzar cotas insospechadas en la vivencia de las virtudes teologales. Alonso de Orozco, fiel a ver en cada una de las estrellas, que forman la corona misteriosa de la mujer del Apocalipsis, alguna de las gracias de María, contempla en la sexta estrella una imagen de la fe de María. La fe adorna a María. Y la adorna de forma muy suya, muy especial. Lo cual es todo un mensaje. "Ahora vemos confusamente, como por medio de un espejo" (1Cor 12,12). Ello indica que, si María fue mujer de fe, y así se deduce del testimonio de la revelación, tuvo que vivir la fe desde esta perspectiva: es decir, de forma confusa y como mirando a un espejo. Este estilo de fe, único posible, hace inaceptable una María que ya lo sabía todo desde el principio. Inaceptable y además antipática. María vivió sumergida en el claro-oscuro de la fe. Desde esta perspectiva, aunque tal vez el fondo de la cuestión es distinto, traigo aquí unas bellas palabras del Catecismo Holandés: “¿Se dio María cuenta exactamente de quién era el que ella daba a luz? Probablemente, no, pues sólo la resurrección comenzó a poner plenamente en claro quién era Jesús. A partir de entonces, pronto se podrían escribir palabras como estos himnos:

'Él es imagen del Dios invisible, primogénito de toda criatura, porque en él fueron creadas todas las cosas' (Col 1,14-16)

O este cántico:

'El cual, siendo de condición divina, no hizo alarde de ser igual a Dios sino que se despojó de sí mismo, tomando la condición de esclavo, hecho semejante a los hombres'. 
Estos textos del Nuevo Testamento fueron escritos antes de los evangelios. Y no son esos solos. También en pasajes posteriores se habla del origen divino de Jesús. Así en el prólogo de Juan:
'Al principio ya existía la Palabra
y la Palabra estaba junto a Dios
y -la Palabra Dios.
Él -la palabra- estaba al principio junto a Dios' (Jn 1,1-2)" ${ }^{51}$.

María vive la fe de la única forma que se puede vivir: en oscuridad, en confianza y en permanente crecimiento. La fe de María, como la de cualquier creyente, se alimenta no tanto de la luz, cuanto del amor. Es, fundamentalmente, un abandono en el i nor infinito de Dios, cuyos planes siempre misericordiosos, triunfan sobre los limitados planes de los hombres. Toda la vida de María queda envuelta en esa atmósfera filial. Habrá momentos difíciles. Incluso, momentos en que parece que se apaga la más tenue luz. Pero lo que nunca declina en su persona es que Yahvé sigue sus planes misericordiosos sobre el hombre. Ella, más que ninguno, tuvo la confianza a pleno rendimiento. Dios no puede fallar, aunque todo diga lo contrario. La confianza de María, la fe fiducial de María, alcanzó su cumbre en los momentos más difíciles de su Hijo. Particularmente, en el momento de la pasión. Los evangelios son parcos, al respecto. Mas el evangelio de Juan refiere una escena que lo ilumina todo. María está firme, junto a la cruz de su Hijo. Está allí firme en la fe como una roca. Y en la hora de Jesús va a recibir del Hijo moribundo una nueva misión. Una maternidad, que no puede quedar reducida a la persona del discípulo bien-amado. Una maternidad que alcanza a toda la comunidad de creyentes. De entonces y de siempre. María fue y es la Madre de Jesús y, desde este momento, va a ser la Madre de los discípulos de su Hijo. Aunque muy conocido, el pasaje es digno de recordarlo aquí: "Jesús al ver a su madre y, junto a ella, al discípulo a quien quería dijo a su madre:

-Mujer, ahí tienes a tu hijo.

Después, dijo al discípulo:

-Ahí tienes a tu madre.

Y desde aquel momento, el discípulo la acogió en su casa" (Jn 19,26-27).

Alonso de Orozco ve en la sexta estrella una imagen de su ve viva. Hablando de las excelencias de la fe, Alonso de Orozco se desgrana en multitud de sentimientos. Como si la grandeza de la virtud le invadiera de tal modo que todos los términos fueran pequeños para retratarla. "Es de tanta

51. Catecismo Holandés, Herder, Barcelona 1969, p. 81. 
necesidad esta virtud teologal, 'que nadie sin ella puede agradar a Dios' (Heb 11,6). Y tiene razón, porque la fe nos dice quién es Dios y qué tratamiento y servicio le hemos de hacer, como a nuestro Creador y Redentor. Es una escuela de buena crianza, (subrayo estas palabras), somos enseñados a reverencia y alabar al Señor del mundo... Nosotros los cristianos siempre hemos de mirar a esta estrella celestial de la fe, obrando según la caridad que la acompaña y cumpliendo la Ley de Dios. Con razón la llamamos estrella del cielo, pues el Apóstol dijo 'ser don de Dios y no por mérito nuestro alcanzado' (Ef 2,8)" 52 .

Alonso de Orozco tiene de la fe una visión netamente intelectual. "Acabada esta peregrinación, entraremos en el palacio real de Dios, que es el cielo empíreo, a ver con clara vista lo que aquí por fe creímos y con amor y caridad amamos. Nuestro Padre dice: 'que la fe es creer las cosas que no se ven'. Luego quien quisiere ver a Dios en el cielo, créale y ámele viviendo en la tierra" ${ }^{33}$.

Es de notar, y ello con satisfacción, que el carácter netamente intelectual, válido para todos los tiempos, pero insuficiente a la hora de entender la fe, queda iluminado y enriquecido con lo que dice acerca de la caridad. La fe entronca directamente con la caridad. Delante de Dios vale sólo la fe, que obra por la caridad (cf. Gál 5,6). María es en esto modelo extraordinario, aun dentro de la sencillez de su vida. Toda su vida está marcada por una fe viva. Una fe que culmina en un inflamado amor a Dios y a los hombres. Su consigna 'hágase en mí según tu palabra' (Lc 1,38c) es algo que marca la trayectoria de toda su vida. Se pone, de entrada, en las manos de Dios. Y ya nunca se alejará de esta postura inicial. Acoge la Palabra de Dios, primero en su mente, y, luego, en su vientre. En esto particularmente María brilla con singular resplandor. Alonso de Orozco ve en la fe de María una gracia que no tiene parangón. "Cuánto resplandeció esta virtud de nuestra Señora, entendámoslo: porque, acabada la plática del ángel, guardó su virginidad, pues había de ser la concepción del Hijo de Dios por obra del Espíritu Santo: luego obedeció. No pidió seña para creer como Gedeón, ni como Zacarías, padre de san Juan, que, por dudar, enmudeció; solamente creyó, sin otro motivo, ni milagro, oyendo la promesa de Dios, intimada por el ángel. Oh qué maravillas fueron obradas en un instante... Mucha virtud tuvo aquel Fiat de Dios, cuando crió el mundo; mas este Fiat de la Virgen mayor eficacia tivivo. La razón es porque cuando Dios creó al mundo, Dios se quedó

52. Alonso De Orozco, Tratado de la Corona de Nuestra Señora, en Obras, III, Madrid, 9736, p. 142.

53. Alonso de Orozco, Ib., 142. 
Dios como antes y el mundo criatura. Mas con esta palabra de nuestra Señora 'hágase', Dios fue hecho hombre y el hombre subió a la dignidad de Dios, por unión con aquella divina persona; la cual fue la mayor obra que jamás se hizo, ni se hará" ${ }^{54}$. En su oración encendida, ferviente, para pedir aumento de fe, Alonso de Orozco se muestra como un verdadero enamorado de María. Hagamos nuestra la parte que aquí se recoge de esta ardiente oración. "Suplícoos, Señora, que para que yo más sirva a su majestad, me alcancéis que de su mano se me dé perfecta fe, imitando la vuestra tan acabada y perfecta... En toda tentación esté firme mi alma, creyendo todo lo que Dios me ha revelado, y la santa iglesia determine, y ha determinado, porque diga con el santo Job: 'con el oído, Se r̃ or, os oí, y, por tanto, ahora mis ojos os ven'. Oiga yo, creyendo con toda firmeza, para que, después de esta vida mortal, vea a mi Criador y Redentor en la gloria" ${ }^{55}$.

\section{VI}

La esperanza es una virtud que forma parte de la trilogía de las virtudes teologales. Ha sido, si se puede hablar así, la cenicienta, debido a un mal tratamiento de la misma. Quedaba como perdida entre la fe y la caridad. Se creía que era una virtud que miraba únicamente al más allá. Aquí no había que esperar nada, o casi nada. Ello hizo que no tuviera mayor influencia precisamente en aquel campo en que debía influir: la transformación de la tierra. A su defectuoso enfoque se debió en parte la apatía de los cristianos en la construcción de la ciudad terrestre. De una ciudad que respondiera a los designios de Dios y en la que habitara la justicia como su piedra angular. De ahí que no fue injustificada la crítica marxista, cuando hablaba de la religión como alienación del hombre. Y también, cuando la consideraba como opio, adormidera del pueblo. Oigamos al mismo Marx: "El hombre es quien hace la religión, no es la religión la que hace al hombre. La miseria religiosa, por una parte, es la expresión de la miseria real, y, por otra, la protesta contra ella. La religión es el suspiro de la criatura oprimida, el alma de un mundo sin corazón, como también es ella el espíritu de las condiciones sociales de donde se ha excluido al espíritu. Ella es, pues, el opio del pueblo" ${ }^{56}$. Todo esto se debe, al menos, en parte, a un enfoque teológico deficiente de la esperanza.

54. Alonso de OrozCo, Ib., 142-143.

55. Alonso DE OROZCO, Tratado de la corona de nuestra Señora, en Obras III, Madrid, 1736, p. 145. 41-42).

56. MARx, C., Introducción a la crítica de la Filosofía del Decrecho, (marzo 1844) (SLR, pp. 
Tal enfoque, y debemos saludarlo con gozo, ha cambiado últimamente. Gracias particularmente a la obra de Moltmann, alimentada por la filosofía del marxista E. Bloch, la esperanza ha recuperado su dinamismo intramundano, sin perder su proyección extramundana. "En la vida cristiana la fe posee el prius (el primer lugar), pero la esperanza tiene la primacía. Sin el conocimiento de la fe, fundado en Cristo, la esperanza se convierte en utopía que se pierde en el vacío. Pero sin la esperanza, la fe decae, se transforma en pusilanimidad y, por fin, en la fe muerta. Mediante la fe encuentra el hombre la senda de la verdadera vida, pero sólo la esperanza le mantiene en esa senda. Así, la fe en Cristo transforma la esperanza en confianza. Y la esperanza dilata la fe en Cristo y la introduce en la vida.

Creer significa rebasar, en una esperanza que se adelanta, las barreras que han sido derribadas por la resurrección. Si reflexionamos sobre esto, entonces esa fe no puede tener nada con la huida del mundo, con la resignación y los subterfugios. En esta esperanza el alma no se evade de este valle de lágrimas hacia un mundo imaginario de gentes bienaventuradas, ni tampoco se desliga de la tierra...

Esta esperanza transforma a la comunidad cristiana en una constante inquietud dentro de aquellas sociedades humanas que quisieran estabilizarse, convirtiéndose en una ciudad permanente. Transforma a la comunidad cristiana en fuente de impulsos siempre nuevos que incitan a realizar aquí el derecho, la libertad y la humanidad, a la luz del futuro anunciado que debe venir. Esta comunidad cristiana está obligada a la 'responsabilidad de la esperanza', que hay en ella ( $1 \mathrm{Pe} 3,15)$. Es acusada 'a causa de la esperanza y de la resurrección de los muertos' (Hech 23,6). Siempre que esto ocurre, la cristiandad accede a su verdad y se convierte en testigo del futuro Cristo" ${ }^{57}$.

Es normal, y fácilmente inteligible, que este enfoque de la esperanza no esté en las reflexiones que sobre ella hace Alonso de Orozco. Él quiere resaltar, usando la imagen de la mujer del Apocalipsis, las gracias de María. Contempla, pues, la esperanza desde la perspectiva de poner la confianza en el Señor y en las promesas que ha hecho. Esperanza de María, tal y como la presenta Alonso de Orozco, es un complemento de la fe. Ella se ha confiado al Señor y no duda, espera sin vacilación, que el Señor cumpla lo que le ha prometido. Causa gran delicia ver cómo Alonso de Orozco habla de la esperanza de María, uniéndola a la fe de María. "Estas dos virtudes, fe y esperan$\mathrm{za}$, son muy hermanas y nada tan a un paso, que de la mayor fe, nace mayor firmeza en la esperanza. En María brilla la esperanza de forma singular... "Sierva soy del Señor, cúmplase en mí lo que Vos, ángel, de su parte me

57. Moltmann, J., Teología de la esperanza, Sígueme, Salamanca 1972, pp. 26-27-28. 
habéis prometido' (Lc 1,38). No solamente de estas palabras entendemos la grandeza de la fe, que nuestra Señora tuvo, creyendo la promesa del ángel san Gabriel. Más aún, de aquí se saca haber tenido perfecta esperanza, que es otra virtud teológica, que acompaña a la fe. Estrella es que alumbra más que el sol en la Sagrada Virgen María; y, como en la fe tuvo el primádo, según ahora vimos, también lo tuvo en esta virtud. Esperó con gran firmeza verse Madre del criador del mundo, y que en este privilegio había de gozar siempre del que ella tanto amaba, que es el de dignidad virginal" ${ }^{58}$.

Alonso de Orozco se entretiene y goza en cantar las excelencias de esta virtud, que forma parte de la corona de María. Una virtud que brilla en María como estrella fulgidísima, hasta el extremo que constituye a María en Madre de la esperanza. Esperanza nuestra la llamamos en este himno mariano, siempre antiguo y siempre nuevo, de la Salve. Alonso de Orozco intenta hacer comprender a sus lectores que María es Madre de esperanza. Para ello se vale de un bello texto del Ben Sirá, el Eclesiástico tradicional. Un texto que Ben Sirá aplica a la Sabiduría y que Alonso de Orozco no tiene reparo en ponerlo a recaudo de María. "Fue tan maravillosa esta esperanza, que la Reina del cielo tuvo, que pudiera decir aquello del Eclesiástico: 'yo soy Madre de amor hermoso, de temor, de conocimiento y de santa esperanza' (24,24). Madre es del que es amor hermosísimo, Cristo Redentor nuestro, pues ella es su verdadera madre. Fue la que más temió con aquel temor filial, que anda hermanado con el amor de Dios. Fue la que entre las puras criaturas más bien conoció los secretos de su Hijo. Llámase Madre de esperanza santa, para que todos aprendamos de ella a confiarnos de Dios y para que la pongamos por intercesora, que nos alcance aumento de esta virtud. Con tal favor no solamente nuestra fe irá aumentándose cada día, más aún, todas las virtudes, mayormente la esperanza viva, que tenemos en nuestro Redentor, de la cual dice san Pablo 'que es sin mácula y que se conserva en los cie$\operatorname{los}^{1 "}{ }^{59}$.

Alonso de Orozco cierra sus reflexiones piadosas sobre la esperanza de María con una ardorosa oración a María, para pedir virtud tan grande. "Suplicad, dice a María, a vuestro Hijo sagrado, que merezca yo oír aquellas palabras suyas: 'porque esperó en mí lo libraré y lo defenderé, porque conoció mi nombre' (Psal 90,14). Espere yo en su misericordia. Sea él mi defensor, reconociendo yo siempre su gran poder y bondad, el cual sólo es poderoso de sacar de grandes peligros a los que de él se fían, librándolos de los

58. Alonso DE OROzco, Tratado de la corona de nuestra Señora, en Obras III, Madrid 1736, pp. 145.

59. Alonso de Orozco, Ib., 147. 
lazos del demonio y de la cárcel de este cuerpo; se les da a sí mismo en premio, dándoles la gloria" ${ }^{60}$. Sin olvidar nada de su belleza, hay que reconocer que Alonso de Orozco se muestra aquí excesivamente deudor a la espiritualidad de su tiempo. Expresiones "como lazos del demonio" y "cárcel de este cuerpo" resultan extrañas a los oídos modernos. Pero, lo hemos dicho ya, nadie se escapa de su entorno cultural y juzgar con ojos de hoy expresiones del pasado no es correcto. Todo en la vida tiene su situación. Esto no hay que olvidarlo nunca.

\section{VIII}

Llegamos a la reina no sólo de las virtudes en general, sino también de las virtudes teologales. Es la virtud, y más que virtud, de la caridad. La caridad es la esencia de la vida cristiana. Es vínculo de la perfección cristiana. (Cf. col 3,14b). Nada se le puede comparar. Sólo el que ama, el que tiene caridad, pasa de la muerte a la vida; de las tinieblas, a la luz (cf. 1Jn 3,14; 2.10.11). La caridad es la gracia de las gracias; el don de los dones; el carisma de los carismas. De ahí que sea el fruto más sustancioso y sazonado de la presencia del Espíritu Santo (cf. Gál 5,22). "El amor de Dios, la caridad, ha sido derramado en nuestros corazones por el Espíritu Santo, que se nos ha dado" (Rom 5,5). Nadie ha cantado las excelencias de la caridad o del amor como Pablo en su primera carta a los Corintios". ¿De qué me sirve hablar lar. lenguas de los hombres y de los ángeles? Si me falta el amor(=caridad), ne soy más que una campana que repica o unos platillos que hacen ruido. ¿De qué me sirve comunicar mensajes en nombre de Dios, penetrar todos los secretos y poseer la más profunda ciencia? ¿De qué me vale tener toda la fe que se precisa para mover montañas? Si me falta el amor, no soy nada. ¿De qué me sirve entregar toda mi fortuna a los pobres, e incluso mi cuerpo a las llamas? Si me falta el amor, de nada me aprovecha" (13,1-3).

Jesús, el maestro incomparable, el hermano, el amigo del hombre, sintió y vivió como nadie la grandeza y las exigencias del amor. El amor, ahora se traduce así la palabra griega agapé, no es derivación o consecuencia de un impulso humano. Tiene, se recordó hace poco, su fuente en el Espíritu Santo. No es fruto, no puede ser, del esfuerzo humano: Esta doctrina o este mensaje son ofrecidos clara y bellamente por Alonso de Orozco. "Esta caridad, reina y vida de las virtudes, reparte el Espíritu Santo en nuestras almas liberalmente. A los Romanos el Apóstol dice así: 'la caridad de Dios es

60. Alonso DE ORozco, Tratado de la corona de nuestra Señora, en Obras III, Madrid 1736, pp. 148. 
derramada en nuestros corazones por el Espíritu Santo, que se nos ha dado (Rom 5,5). Es decir, que es derramada por el Espíritu Santo da a entender la gran abundancia con que nos da Dios esta virtud, siendo la más excelente de todas. Y la que habilita nuestra alma sobrenaturalmente, para poseer la vida eterna. Esta es la tasa y medida por donde se nos da la gloria; y el que mayor caridad tiene, cuando muere, mayor gloria recibirá en el cielo" ${ }^{61}$.

Hay un dato en la exposición de Alonso de Orozco que puede ayudar mucho a la hora de llevar a la praxis las exigencias de la caridad. Habla el Beato de tres grados de caridad en el terreno práctico. Grados que miran a tres situaciones en las que el creyente puede encontrarse en el camino de la santidad. Se trata de los que están iniciando el camino, principiantes, de los que van adelante en él, progredientes y de los que se hallan muy cerca de la meta, perfectos. "Tres grados de caridad se hallan entre los cristianos: unos son principiantes, otros aprovechantes (sic), y otros perfectos. Nuestro Padre san Agustín dice así: 'la caridad, que ha nacido, va creciendo, y, crecida, fortalécese, y es perfecta'; el nacer conviene a los principiantes; el crecer, a los aprovechantes; ser fuertes, a los que ya son perfectos'. 'El grano de trigo sembrado en la tierra, dice Nuestro Salvador, nace, produce espiga y lleva fruto' (Mc 4,28). Aquí declara estos tres grados de caridad: nace, en los que comienzan a amar a Dios; crece en los que van aprovechando; da fruto sazonado en los que ya son perfectos" ${ }^{62}$.

Aunque no resulta fácil establecer grados en la caridad, para medir la caridad no hay termómetros, Alonso de Orozco ofrece aquí un camino que, si tiene principio, nunca alcanza la meta de forma definitiva, mientras se camina lejos del Señor. La caridad puede poseerse con mayor o menor intensidad. Y siempre podrá alcanzar metas más ambiciosas, hasta que llegue la hora de su consumación en la presencia de Dios. Es todo un buen estímulo para no hacer alto en la marcha de los caminos hacia Dios. Esto vale siempre y vale, por tanto, para el caso que nos ocupa. Estimula a no pararse en el camino.

No deja Alonso de Orozco de tratar en campo tan precioso, pero no exento de complicaciones, el tema del orden en el amor. Se nota el eco del gran Padre Agustín. "Nuestro Padre san Agustín dice que cuatro cosas se han de amar con amor cristiano: la primera es Dios; la segunda, nosotros mismos; la tercera, el prójimo; y la cuarta, la salvación del prójimo más que nuestro cuerpo. Amamos a Dios como a principio nuestro, que nos crió y

61. Alonso DE OROzco, Tratado de la corona de nuestra Señora, en Obras III, Madrid 1736, p. 149.

62. Alonso de Orozco, Ib., 150. 
como a fin, pues es nuestra bienaventuranza. Es de notar que, aun acá en este destierro, podemos cumplir en alguna manera aquel mandamiento: 'amarás a Dios con todo el corazón' (Mt 22,37). Amarse cada cristiano a sí mismo con amor santo, cuando, para conservar la vida, come y duerme, dando gracias a su Creador; no comiendo por comer, ni durmiendo por dormir, sino por cumplir la volntad de Dios...

Hemos también de amar al prójimo según el orden de la caridad, porque es hecho a imagen de Dios y capaz de bienaventuranza como nosotros. La regla de este amor santo, dice el Señor, sea cada uno, de manera que todo lo que es bueno y quiere para sí, ha de querer para el prójimo; y lo que no quiere para sí, tampoco lo ha de querer para otro. ¡Oh cuán poco se usa esto en el mundo, siendo una Ley tan suave y tan acomodada a razón!

Finalmente, este orden de caridad demanda que amemos más la salvación del alma del prójimo que la vida temporal nuestra. Cuanto es más el alma del prójimo que nuestro cuerpo, terrón de tierra, tanto merece ser amado más que el cuerpo propio. Esto es lo que dijo san Juan: 'Así como Jesucristo dio su vida por nosotros, así debemos nosotros dar nuestra vida por salvar muchos hermanos'. (1 Jn 3,6). Esto se entiende en caso de necesidad, porque solamente obliga entonces" ${ }^{63}$.

Si María ha brillado por su fe, ha poseído una gran esperanza, no puede quedar rezagada en el tema de la caridad. Aquí ha llegado María a su cumbre más excelsa, después de su Hijo. Y se entiende con facilidad. La caridad, se dijo anteriormente, es el vínculo de la perfección, es decir, de la santidad. Cuanto más excelsa es la caridad, tanto más grande es la santidad. Y María no es sólo santa. Es Santísima. Así es y así la saluda el pueblo entero de Dios. Su nombre más frecuente, el nombre por antonomasia o la expresión con que se la distingue, es éste: Virgen Santísima. Alonso de Orozco comienza la exposición de la caridad, contemplada en la octava estrella de la corona, con estas palabras: "'Sierva soy del Señor: hágase en mí lo que habéis, ángel, prometido'. (Lc 1,38). Es tan rica mina esta respuesta de Nuestra Señora, que se acabará el tiempo y no se hallará el fin de los tesoros, y virtudes, que en ella están encerrados. No sólo gran fe, y esperanza, como ya se ha dicho, más aún la caridad, que es la reina de las virtudes teologales, dio aquí grandes resplandores en esta respuesta. Digo, que como no bastara otra menor caridad, que la de Cristo, para padecer tanto como padeció: tampoco bastará otra caridad menor que la de Nuestra Señora tuvo, para sufrir lo que sintió, compadeciéndose de las afrentas y dolores de su precioso Hijo. Para

63. Alonso De Orozco, Tratado de la corona de nuestra Señora, en Obras III, Madrid, 1736, pp. 153-154. 
entender se ha de notār, que nuestro Dios, como es luz eterna, trata con sus siervos muy a la clara, y sin engaño... El Señor del mundo, Verdad suma, que ni puede ser engañado, ni engañar, cuando recibe a uno en su servicio, luego le da un memorial de lo que ha de padecer por su amor... Con su sagrada Madre lo hizo así, cuando la eligió para tal dignidad: y ella, con mayor voluntad que san Pablo, dio gracias por los trabajos, que había de padecer sesenta y tantos años, que en este destierro vivió. Había leído a Isaías, Jeremías y los otros profetas, que hablaban del Mesías, y de la pasión, que había de padecer por la salud del linaje humano: y entendiendo esto con gran caridad, cuyo oficio es amar a Dios, y al prójimo, según dice san Jerónimo, para honra de dios, y porque los hombres se salvasen, con alegría determinó aceptar la dignidad de Madre de Dios, sabiendo lo mucho que había de padecer" ${ }^{64}$.

En estas palabras de Alonso de Orozco hay cosas dignas de admiración y hay cosas que producen extrañeza. Uno admira la raíz en donde él encuentra el motivo para hablar de la caridad subidísima de María. Está en su vinculación a Cristo y, por tanto, a todo su misterio salvífico, en el que entra con categoría de primer lugar la muerte en la cruz. Jesús mismo había dicho: "no hay mayor prueba de amor que dar la vida por los amigos" (Jn 15,13). Ante el misterio de la muerte de Jesús Pablo hace las siguientes atinadas reflexiones: "Incapaces como éramos de salvarnos, Cristo, en el momento oportuno, murió por los culpables. Difícil cosa es afrontar la muerte, aunque sea en favor de una persona buena; no obstante, por una persona buena de verdad, tal vez alguien èstaría dispuesto a morir. Pues bien, Cristo murió por nosotros, que éramos pecadores: ¿puede haber mayor prueba del amor que Dios nos tiene?" (Rom 5,6-8). La prueba más grande del amor de Jesús a sus hermanos está en la muerte de Cruz. Y se puede decir que María participó de este misterio de dolor como nadie. Allí, en el monte del dolor, junto a la cruz de donde pende su Hijo querido, está firme, como una roca, solidaria como ninguna. Ella sufre en lo profundo de su corazón lo que su Hijo adorado sufre en su cuerpo. Bernardo de Claraval, el citarista incomparable de María, escribe a propósito de este episodio: "Él (Jesús) pudo morir en el cuerpo, y ¿no pudo María compartir su muerte en el corazón? Aquello lo realizó una caridad superior a toda otra caridad. Y esto lo realizó una caridad que después no ha sido igualada" ${ }^{65}$.

64. Alonso De Orozco, Tratado de la corona de nuestra Señora, en Obras III, Madrid, 1736, pp. 148-149. 15.

65. BeRnARDo De Claraval, Sermón en el domingo dentro de la octava de la Asunción, 14- 
Para nuestra sensibilidad moderna resultan extrañas algunas afirmaciones de Alonso de Orozco, que, lógicamente, hay que verlas desde la perspectiva de su tiempo. Extraña esa ciencia que María tenía de los acontecimientos que, poco a poco, sus ojos iban presenciando. Algo se dijo sobre el tema. María tuvo, era necesario, un crecimiento en el conocimiento tanto de la persona de su Hijo como de lo que Él era protagonista. Su conocimiento, al respecto, no fue perfecto desde el principio, es decir, desde el momento de la encarnación. A veces, y el evangelio de Lucas se hace eco de este hecho, las cosas desbordan su capacidad comprensiva. Entonces opta por acogerlas en su corazón, para meditarlas pausadamente y poder así penetrar más en el misterio (Cf. Lc 2,19; 2,51). Esto hace muy problemático lo que Alonso de Orozco dice acerca de que "María determinó aceptar la dignidad de Madre de Dios, sabiendo lo mucho que había de padecer".

También resulta un tanto extraño la relación que Alonso de Orozco establece entre el dolor y la voluntad de Dios. El dolor, como tal, no entra en los planes de Dios. Más aún es una realidad negativa a superar en el nuevo cielo y la nueva tierra. Los padecimientos de Cristo son la consecuencia directa de la malicia humana. Jesús tenía que morir. Es el tributo de todo hombre. Pero el género de muerte depende absolutamente de los hombres. La idea de un Dios, que determina que su Hijo, hecho hombre, muera en la cruz para reparar la deuda del pecado humano se debe más al ámbito de lo cristiano interpretado desde la religión que desde la fe. "La muerte de Jesús fue en sí misma, en su escueta realidad histórica, un simple suplicio como otros tantos miles y miles que la violencia ha infligido, inflige y habrá de infligir a los hombres. El descubrir en él un alcance salvífico, más allá del mero dato, depende de la interpretación. La mayor parte del Nuevo Testamento no es otra cosa más que una amplísima tarea -en iglesia, bajo la inspiración del Espíritu y con la ayuda del Antiguo Testamento- de interpretación del acontecimiento-Jesús en orden a expresar su valor salvífico para la humanidad. Y es esta interpretación, realizada en un contexto de fe, la que nos proponemos descubrir en este libro.

Pero esa misma muerte de Jesús, ese mismo y simple acontecimiento, puede perfectamente deslizarse a otro contexto -el de la religión, por ejemplo- y ser víctima de una interpretación aberrante. No basta, pues, para estar en la verdad con repetir que 'la sangre de Jesús nos purifica de nuestros pecados'. Sobre todo en nuestros días, en que somos conscientes de la ambigüedad del lenguaje y nos gusta descubrir, tras las palabras, sus contenidos reales, porque son éstos los que hacen vivir, y no las palabras ni las fórmulas, por ortodoxas que sean" ${ }^{66}$.

66. VARONE, F., El dios 'sádico'. ¿Ama Dios el sufrimiento? Sal Terrae, Santander 1988, 18-19. 
El entramado de esta visión religiosa de la redención está en dos presupuestos muy presentes en la reflexión teológica sobre el tema. Se trata, primero, de la universalidad de la caída humana, todos los hombres son pecadores, y segundo, en la injuria de valor infinito que se ha hecho a Dios. Ni hay un inocente que pueda suplir al culpable, ni un deudor que pueda saldar la cuenta. Colocados en esta situación, no queda otra alternativa de salvación que Dios-Padre determine que sea su propio Hijo, hecho hombre y con capacidad de sufrir, quien ofrezca esa salvación exigida por su justicia inexorable. Ya tenemos armado todo el tinglado. Por designio divino Jesús tiene que someterse a una muerte y a una muerte de cruz. Así ofrecerá a Dios una reparación más que suficiente en favor de quienes estaban incapacitados para ello. "No hay en toda la humanidad un solo inocente cuya muerte pudiera ser todavía un valor 'virgen', no hipotecado por el castigo. Además, aunque lo hubiera, ¿podría tener su muerte un valor infinito, capaz de compensar la infinita ofensa infligida al Dios infinito? La situación, pues, está doblemente complicada, y Dios podría perfectamente dejar en ella al hombre para siempre; a fin de cuentas, habría sido pura justicia.

Pero habría sido una justicia incompleta, porque, si bien es justo que el pecado sea castigado, también es propio de la justicia divina el que la ofensa sea reparada. Así pues, Dios enviará a su propio Hijo al corazón mismo de la humanidad: convertido en hombre inocente en medio de hombres pecadores, su muerte podrá ser totalmente 'satisfactoria'. Hijo de Dios hecho hombre, su muerte tendrá un valor infinito y podrá, por tanto, compensar perfectamente la ofensa infinita" ${ }^{67}$. ¿Qué poco atrayente es la imagen de este dios (lo pongo en minúscula, porque es un dios falso) que pide la muerte de su Hijo, por supuesto amado, para salvar sus propios intereses, no al hombre! Sólo la interpretación de la redención desde la fe, no desde la religión como acontece aquí, puede evitar tan graves inconvenientes. La muerte de Jesús es redención del hombre y para el hombre porque ha sido la consecuencia de una fidelidad inquebrantable a la misión recibida. Por eso revela un Dios diferente. Es el Dios de la misericordia, no del sacrificio". A ese Dios que se resiste a las falaces construcciones del poderío humano, a ese Dios 'suave brisa', Elías sólo pudo reconocerlo al final de un largo drama; pero así se fundaba la gran tradición profética que une a Dios, el rechazo del poderío y la solicitud por el oprimido en una verdad inseparable. Una tradición que tiene su broche de oro en Jesús.

Pero que no se deje engañar el lector por esta reflexión acerca del poder y acerca de la praxis concreta de Jesús: Jesús no se diluye en lo social; pero tampoco se diluye en Dios. Jesús realiza perfectamente la síntesis profética,

67. VARONE, F., Ib., 19-20. 
que quiere que la pasión por Dios sea inseparable de la pasión por el hombre (concreto), porque el profeta se encuentra habitado por la pasión de Dios, y ese Dios busca una alianza viva con el hombre; y en una alianza viva, la verdad o la mentira de una parte repercute inmediatamente en la otra. En su búsqueda de la verdad, el profeta se encuentra tanto con quienes detentan el poder falaz (a los que hay que liberar). Y en ambas cosas, lo que está en juego es la misma verdad de Dios...

Digamos... "que Jesús no va a morir en virtud de un sistema penal de compensación y reparación formal por los pecados; Jesús va a morir por haber insistido hasta el final en revelar a Dios como diferente y por haberlo hecho con una praxis diferente de la del poder religioso, haciéndose cercano y liberador del hombre concreto y, al mismo tiempo, desenmascarando al poder religioso como una instancia de dominación, ajena a Dios y enemiga del hombre" ${ }^{68}$.

Tras estas matizaciones sobre un tema siempre difícil como es el problema del dolor, quiero acabar el artículo recordando aquí algunos pensamiento de la encendida oración que hace Alonso de Órozco para pedir la virtud de la caridad: “ $¡ O$ Oh Reina del cielo!, si de la Magdalena dijo el Señor que 'había amado mucho' (Lc 7,47), habiendo sido tan pecadora, ¿qué diremos de Vos, inocentísima y gran amadora de vuestro Criador y Señor? Por este inflamado amor, que siempre, Señora, tuvisteis a Dios, os suplico que seáis mi Abogada, para que yo ame al que es bondad infinita, hermosura de todo lo creado, 'flor del campo, y azucena olorosa de los valles' (Cant 2,1), que son los humildes. ¿A quién tengo de amar, sino al que me crió a su imagen y semejanza?... Con humildad os suplico me seáis intercesora, para que de aquí adelante no ame sino a mi Dios y Salvador, de manera que ninguna cosa creada se enseñoree de mi corazón" ${ }^{69}$.

Benito Domínguez SÁNCHEZ $82-83$.

68. VARONE, F., el Dios sádico. ¿Ama Dios el sufrimiento? Sal Terrae, Santander, 1988, pp.

69. Alonso DE OROZCO, Tratado de la corona de nuestra Señora, en Obras III, Madrid, 1736, 154. 